\title{
Hürriyeti Bağlayıcı Cezaların Ortaya Çıkışında Etkili Olan Koșullar
}

\author{
Effective Conditions on Emergence of Imprisonment
}

\section{Hakan KARAKEHYA ${ }^{1}$ [D, Hande ÖZGER ${ }^{2}$ (ㄹ}

\author{
${ }^{1}$ Prof. Dr., Anadolu Üniversitesi, Hukuk Fakültesi, Eskişehir, Türkiye
}

${ }^{2}$ Uzman, Zafer Kalkınma Ajansı, Kütahya, Türkiye

ORCID: H.K. 0000-0001-5028-1216; H.Ö. 0000-0001-9279-1169

\section{öz}

Modern süreç, özellikle 17. yüzyılın ikinci yarısından itibaren Avrupa'da başlayan ve sonrasında tüm dünyayı etkisi altına alan, sosyal, ekonomik ve kültürel değişim sürecini ifade eder. Modern sürecin ya da daha yaygın kullanımı ile modernizmin üç temel sacayağı vardır. Bunlar; sanayileşme, sanatsal-kültürel değişim ve aydınlanmadır. Modern sürecin kamusal cezalandırmanın değişimine ve dolayısıyla hapishanenin doğuşuna zemin hazırlayan alt unsurları ise; 1) İnsanın öneminin artması, 2) Bilimselliğinin temel değer haline gelerek, yarının daha güzel olacağı inancının yaygınlaşması, 3) Disiplin kavramının yaygınlaşması ve gözetimin öneminin farkına varııması şeklinde sıralandırılabilir. Gerek insan bedeninin öneminin artması gerekse de insanın kendi yaşam yolunu aklıyla belirleyebilen bir birey olarak görülmeye başlanması, ona karşı insan onuruyla bağdaşmayan ve doğrudan fiziksel şiddet içeren cezaların uygulanamayacağı düşüncesini ortaya çıkarmıştır. Bilimselliğin temel değer haline gelmesi ve bilim sayesinde geleceğin insanlık için daha güzel olacağı düşüncesinin yaygınlaşması ise suçluların da bilim yoluyla ıslah edilebileceği düşüncesini ortaya çıkarmıştır. Son olarak disiplin kavramı da modern süreçte yaygınlaşmış ve toplum içinde disiplini sağlamanın en etkili yolunun gözetim olduğu görülmüştür. Hükümlülerin gözetlenmesi ve böylelikle disipline edilmesi için en uygun mekanlar olarak ise hapishaneler inşa edilmiştir.

Anahtar Kelimeler: Hapishanenin doğuşu, modernizm, gözetim

\section{ABSTRACT}

The modern process refers to the process of social, economic and cultural change that began in Europe, especially from the second half of the 17th century, and then influenced the whole world. The modern process has three basic elements: industrialization, artistic-cultural change, and enlightenment. The sub-elements of the modern process that pave the way for the change of public punishment and thus, the birth of prison are: 1) Increased valuing of human beings, 2) The spread of the belief that tomorrow will be better by accepting science as fundamental value, and 3) The spread of the concept of discipline and awareness of the importance of surveillance. Both the increase in the importance of the human body and the fact that human beings are perceived as individuals who can determine their own way of life have led to the idea that punishments which are incompatible with human dignity and which involve direct physical violence cannot be applied to human beings. The fact that science has become a fundamental value and the idea that the future will be more beautiful for humanity through science has led to the idea that criminals can be rehabilitated in confinement through science. Finally, the concept of discipline has become widespread in the modern process and it has been seen that surveillance is the most effective way of ensuring discipline in the society. Prisons have been built as the most suitable places for the surveillance and thus, the disciplinary reform of the criminals.

Keywords: Birth of prison, modernism, surveillance

Submitted: 17.08.2020 • Revision Requested: 14.09.2020 • Last Revision Received: 01.12 .2020 - Accepted: 02.12 .2020 • Published Online: 28.12 .2020

Corresponding author: Hande Özger, E-mail: hande.ozger@zafer.gov.tr

Citation: Karakehya H, Özger H, 'Hürriyeti Bağlayıcı Cezaların Ortaya Çıkışında Etkili Olan Koşullar' (2020) 8(2) Ceza Hukuku ve Kriminoloji Dergisi-Journal of Penal Law and Criminology, 169. https://doi.org/10.26650/JPLC2020-0022 


\section{EXTENDED ABSTRACT}

Like all social disciplines, law undergoes certain transformations according to time and place. Criminal law is also affected by these changes as a branch of law. An action considered a crime for a while may be decriminalized and may even come to be described as a virtuous behavior. Again, some types of punishment that are applied as the most correct form can be abandoned over time for reasons such as not performing the function of protecting the society from crime. This was similar in the modernization process.

The modern process refers to the social, economic, and cultural change that started in Europe in the second half of the 17th century and subsequently influenced the whole world. Physical punishments applied in pre-modern punishment systems were abandoned during the modern process and replaced almost entirely with prison sentences. It is considered that some sub-elements of the modern process laid the groundwork for the change in public punishment, hence, the birth of the prison in this transformation. These sub-elements are increased valuing of human beings, the spread of the belief that tomorrow will be better by accepting science as fundamental value, and the spread of the concept of discipline and awareness of the importance of surveillance.

In the modern process, the importance of humanity has increased with the effects of industrialization and the humanism movement which emerged with the idea of enlightenment. While for industrialization, humanity has gained more importance as a productive power, humanism has enabled the human being to be accepted as an entity, a complex unity of body and soul. As a matter of fact, in the pre-modern period, the body was accepted only as a means of ripening the soul and was despised. Modern punishment systems are so designed that they do not harm the body, which is both a part of the human being and has the power of production and/but disciplines them to contribute to the development of mechanized individuals following the requirements of the industrial society.

It can be said that the hope for the future has increased in the modern process because science has become the fundamental value and with it a strong trust in science. Indeed, when the works of modern thinkers are examined, a firm belief is seen that tomorrow will be better. Underneath this thought lies the trust in reason, science and the human being who will attain the true truth through reason and science. Reason and scientificity came to the fore with the effect of enlightenment thought in the modern process; when it was believed that human beings will dominate nature through reason and science and will use it for their own benefit. According to modernism, humans are also a part of 
nature and criminals can be brought back into society disciplined by means of reason and science. Hence the belief that tomorrow will be more beautiful as a result of the fact that science had become the fundamental value in the modern process and the strong trust in science has led to the idea of rehabilitation of the criminals.

Another issue affecting the punishment system in the modern period is the spread of the concept of discipline and an understanding of the effectiveness of surveillance. As mentioned above, the main purpose of punishment systems in the modern period is to discipline the criminal. Although it is held that disciplining is generally a process of harmonization with the society, it can be said that the main purpose is to create mechanized individuals following the requirements of the industrial society. This function is carried out not only through prisons but also through schools, religious institutions and military institutions to spread to the whole society. In the modern period, the power of the body increased through discipline and by controlling this power very effectively, the body was imprisoned in a strict dependency relationship. In addition to places such as schools, hospitals, religious institutions, and production areas, prisons have also been important application areas of discipline. These areas are already in integrity between each other so that the mechanical individuals mentioned in a holistic structure are developed. Regarding discipline, it is important to be able to discipline an individual or a society; it is first required to know and understand it well. Understanding the individual or society which is desired to be disciplined passes through surveillance. Therefore, the most important tool of the discipline institutions in the modern process has been surveillance. Consequently, prisons were built as the most suitable places for the observation and, thus, discipline of the criminals. 


\section{Giriş}

Günümüz ceza adaleti sisteminde hürriyeti bağlayıcı cezalar (hapis cezaları) merkezi bir öneme sahiptir. ${ }^{1}$ Özellikle hükümlüyü 1slah, suçla mücadele ve insanilik açısından birçok handikabının olduğu geniş kitlelerce kabul edilse de insanlık hala hapis cezasının yerini alabilecek bir cezalandırma türü bulabilmiş değildir. ${ }^{2}$ Bununla birlikte insanlığın hürriyeti bağlayıcı cezalara geçişi de insanlık adına önemli bir aşamadır. Nitekim hapis cezası her ne kadar modern bir kavram olsa da cezalandırmanın tarihi insanlık tarihi kadar eskidir. Hatta bazı kutsal kaynaklara göre, insanlığın dünyadaki başlangıcı, ilk insana verilen bir cezanın infazından kaynaklanmaktadır. ${ }^{3}$

İnsanlık tarihinin en başından itibaren mevcut olup günümüze kadar süregelen cezalandırma olgusu tarihsel ve sosyolojik gelişmelere bağlı olarak çeşitli türlerde ortaya çıkmıştır. Hürriyeti bağlayıcı cezaların, modern döneme kadar, hapis cezaları gibi sistematik bir kapatma ve gözetim biçiminde uygulanmadığı görülmektedir. $\mathrm{Bu}$ döneme kadar hürriyeti bağlayıcı cezalar, sürgün ya da küreğe mahkûm etme gibi sistematik olmayan şekillerde ortaya çıkmaktadır. Belirli bir mekâna kapatma ise ancak idam cezasının infazını bekleyen mahkûmun, bekleyeceği süre için kapatılması ${ }^{4}$ veya öldürülmesi uygun görülmeyen kimselerin zindan denilen yerlerde tutulması şeklinde

1 "Ceza, suç teşkil eden fiilleri kusurlu irade ile işleyenler hakkında devlet eliyle uygulanan ve onları bazı yoksunluklara tabi kılan, sosyalleştirme amacına yönelik olan ıstırap verici, korkutucu ve caydırıcı bir yaptırım türüdür.” Mahmut Koca-İlhan Üzülmez, Türk Ceza Hukuku Genel Hükümler (Seçkin Yayınevi, Ankara 2019) 559. Bu bağlamda “cezanın temel özelliği kișiyi yoksunluğa maruz bırakmaktır.” İzzet Özgenç, Türk Ceza Hukuku Genel Hükümler (Seçkin Yayınevi, Ankara 2019) 715. Modern cezalar arasında merkezi konumda bulunan hapis cezası ise "kișinin fiziksel olarak hareket edebilme özgürlüğünün kısıtlanması şeklinde yerine getirilen cezadır." Hamide Zafer, Ceza Hukuku Genel Hükümler (Beta Yayınevi, İstanbul 2019) 612. Modern dönemde hapis cezalarının bu merkezi konumuna karşın birçok devletin adalet sistemi içerisinde para cezalarına yer verildiği de görülmektedir. Para cezasının kabul edilmesinin nedenleri konusunda ayrıntılı bilgi için ayrıca bkz. Berrin Akbulut, Ceza Hukuku Genel Hükümler (Adalet Yayınevi, Ankara 2019) 871.

2 Söz konusu handikaplara ilișkin olarak bkz. Hakan Karakehya, 'Hürriyeti Bağlayııı Cezaların İnfazıyla Hükümlünün Islahının Sağlanması Mümkün Müdür?’, Dr. Dr. h.c. Silvia Tellenbach’a Armağan (Seçkin Yayıncılık, Ankara 2018) 1077 vd.

3 Eski Ahit’te Yaratılış Bab’1 3:1-21 bölümünde ve Kuran-1 Kerim'de Bakara Suresi’nin 35 ila 37. ayetleri ile A'raf Suresi'nin 24. ayetinde insanoğlunun bir ceza olarak cennetten dünyaya gönderilişi anlatılmaktadır. Eski Ahit’teki ilgili bölümler için bkz. < https://www.kitabimukaddes.com/kutsal-kitap-hakkinda-bilgilendirmeve-tam-metni/eski-antlasma/yaratilis> accessed 10 July 2019. Kuran-1 Kerim'deki ilgili bölümler için bkz. $<$ https://kuran.diyanet.gov.tr/mushaf/kuran-meal-2/bakara-suresi-2/ayet-36/diyanet-isleri-baskanligi-meali-1> accessed 10 July 2019 ve <https://kuran.diyanet.gov.tr/mushaf/kuran-meal-2/araf-suresi-7/ayet-24/diyanetisleri-baskanligi-meali-1> accessed 10 July 2019. İncil'de yani Yeni Ahit’te insanoğlunun bir ceza olarak dünyaya gönderilişi hakkında diğer kutsal kaynaklardaki kadar ayrıntılı bir tasvir bulunmamaktadır. Nihangül Daştan, 'Cennetten Kovulma Motifinin Semavi Dinler ile Bazı Mitolojilerdeki (Sümer, Türk ve Yunan) Görünümü’ (2014) (36) Türklük Bilimi Araştırmaları Dergisi 64.

4 Timur Demirbaş, 'Hürriyeti Bağlayıı Cezaların ve Cezaevlerinin Evrimi', Hapishane Kitabı (Kitabevi Yayınları, İstanbul 2005) 5. 
istisnai olarak uygulanmıştır. Bunun yanında yargılaması hemen bitirilemeyenlerin kapalı tutulduğu mekânlar hapishaneyi anımsatsa da modern sürece kadar yaygın olarak kullanılan bir hürriyetten yoksun kılma cezası olmadığ 1 gibi uzun süreli bir tutukluluk da vaki değildir. Ayrıca bu tür istisnai uygulamaların gerçekleştirildiği yerler bakımından, modern dönemdeki gibi örgütsel olarak yapılandırılmış bir hapishane sisteminden de bahsedilemez. Modern öncesi dönem cezalandırma sistemlerindeki esas cezaları bedene karşı olan ve fiziksel şiddet içeren cezalar oluşturmaktadır. ${ }^{5}$

Toplumda çok uzun yıllardır süregelen uygulamalar herhangi bir soruna neden olmadığ 1 sürece -ve hatta bazen birtakım sorunlara neden olsa bile daha iyi bir seçeneğin olmaması gibi gerekçelerle- uygulanmaya devam etmektedir. Uzun yıllardır süregelmeleri dolayısıyla toplumda ve yöneticilerde bu uygulamalara karşı bir aşinalık ve alışmışlık oluşmakta ve bunlar gündelik bir mesele olarak irdelenmemektedir. Fakat bu uygulama en başında nasıl ortaya çıkmıştır? Söz konusu uygulama, toplumsal bir gerçeklik olarak hayatımızda yer etmiyor olsaydı onunla karşılaştı̆̆ımızda onu nasıl algılayacaktık? Hürriyeti bağlayıcı cezaların tarihi iki yüz yılı aşmıştır. Bu demektir ki halihazırda dünya üzerinde yaşamını sürdürmekte olan her birey hapis cezalarının olduğu bir dünyaya gözlerini açmıştır. Bu nedenle hapis cezasına aşina olmayan bir bakış ile konuya yaklaşmamız imkânsızdır. Bu noktada Ursula K. Leguin'in Mülksüzler adlı romanından bir bölüm hapis cezasına aşina olmayan bir bakışın nasıl olabileceği hakkında bize fikir verir. "Mülksüzler" fantastik bir kurgudur ve romanda Anarres ve Urras adında iki ayrı dünyadan söz edilir. Annares’te bir devrim gerçekleşmiş ve devrimden önce hapis cezası uygulanmaktayken devrimle hapis cezaları kaldırılmıştır. Roman devrimden yıllar sonrasında geçmektedir ve Anarres’te o dönemde yaşayan insanlar bizlerin aksine hapis cezalarının olmadığı bir dünyaya doğmuşlardır. Romanda 10-12 yaşlarında bir grup erkek çocuğun tarih öğretmenlerinden hapis cezalarını dinlemelerinin ardından, önce oldukça şaşırmaları sonrasında ise mahkûm, hâkim, gardiyan gibi rollere bürünerek hapis cezasını denemeye kalkışmaları anlatılır. Mahkûm olarak seçtikleri bir arkadaşlarını önce dört saat ve hemen sonrasında yirmi dört saat bir odaya kapatırlar. Çocukların bu oyunu oynarken her adımdaki şaşkınlıkları ve arkadaşlarını hapisten çıkarırken, arkadaşlarının içinde bulunduğu durum karşısında yaşadıkları dehşet hapis cezalarının olmadığı bir dünyayı tasavvur etmek açısından günümüz insanına fikir verir niteliktedir. ${ }^{6}$

5 Michel Foucault, Hapishanenin Doğuşu (İmge Kitabevi, Ankara 2017) 101, 105.

6 Bahse konu, hapis cezası olmayan dünya tasviri için bkz. Ursula Kroeber Le Guin, Mülksüzler (Metis Yayınları, İstanbul 2019), 35-40. 
Elbette ki bizler kurgusal ya da fantastik bir dünyada yaşamamaktayız. Bu örnek hapis cezalarının, cezalandırma sistemleri için yanlış ya da faydasız bir uygulama olduğu anlamına da gelmemektedir. Vurgulanmak istenen nokta şudur: hürriyeti bağlayıcı cezaların daha önce hiç uygulanmadıkları şekilde uygulanmaya başlaması nasıl gerçekleşmiştir? Yani hürriyeti bağlayıcı cezaların, hapishaneler inşa edilerek, buralarda sistematik bir biçimde uygulanan, gözetimin en önemli unsur olduğu ve infazın yapılandırılmış bir infaz teşkilatı eliyle yürütüldüğü cezalara dönüşmesinin altında yatan nedenler nelerdir?

Modern öncesi dönemde ceza hukukunun amacı mağdurun intikamının alınması ve suçların önlenmesi iken modern dönemde mağdurun intikamının alınması işlevi sahneden çekilmiş ve suçların önlenmesi işlevine odaklanılmıştır. ${ }^{7}$ Suçların önlenmesi, ceza hukukunun genel ve özel önleme amaçlarının nihai hedefidir. Ancak dünya genelinde cezaların suçları gerçekten önleyip önlemediğine ilişkin tartışmalar sürmektedir. Bilhassa nöropsikiyatri çalışmaları 1şığında irade özgürlüğü kavramı çevresinde gelişen bu tartışmaların konusunun büyük bir kısmını hapis cezaları oluşturmaktadır. Hapishanelerin gerçekten ceza adaletinin gerçekleşmesi bakımından işlevsel olup olmaması gibi hususların cevaplandırılabilmesi için özgür iradeye ilişkin nörohukuk çalışmaları kadar cezalandırmanın tarihi ve belli cezalandırma türlerinin hangi şartlar altında ortaya çıktığı gibi hususlar da önem arz etmektedir.

Belirttiğimiz üzere hapishanelerin tarihi iki yüz yılı geçmiştir. Hürriyeti bağlayıcı cezalar modern öncesi dönemde istisnai olarak uygulanmış olmakla birlikte, insanları işledikleri suçlardan dolayı yaygın ve örgütlü olarak bir mekâna kapatmak, burada onu devamlı gözetleyerek 1slah etmeye çalışmak, modern dönemde rastlanan uygulamalardır. Biz bu çalışmamızda modern süreçte hürriyeti bağlayıcı cezaların ortaya çıkışını etkileyen koşulları tespit etme amacında olacağız. Bu bağlamda çalışmada öncelikle modernizm kavramı üzerinde durulacak ve "modern süreç" terimiyle ifade edilenin ne olduğu ortaya konulacaktır. Daha sonra modernizmin temel unsurları ele alınacak ve son olarak modernleşme sürecinde hürriyeti bağlayıcı cezaların hangi koşullar altında ortaya çıktığı üzerinde yoğunlaşılacaktır. Bunun dışında hürriyeti bağlayıcı cezaların gelişim süreci, çeşitlenmesi, güvenlik tedbirlerinin ortaya çıkışı, vb. konular çalışmamız kapsamına girmemektedir. Bu hususlar başkaca çalışmaların konusu olabilir; ancak başlığımızdan da anlaşılacağı üzere bu çalışmanın konusu değildir. Çalışmanın, hapis cezasını ortaya çıkaran koşulları irdelemek suretiyle, bu

7 Frank D. Day, 'Ceza Hukukunun Kökeni ve Doğası' (2011) 6 (16) Ceza Hukuku Dergisi 243. 
cezalandırma biçimine yönelik eleştirilerde, aydınlatıcı ve ön açıcı bir etkiye sahip olması umut edilmektedir.

Son olarak belirtmek gerekir ki; çalışmamamızın başlı̆̆ı, "hürriyeti bağlayıcı cezaların ortaya çıkışında etkili olan koşullar” olarak belirlenmiştir. Ancak metin okunduğunda, sadece Batı Avrupa'da hürriyeti bağlayıcı cezaların ortaya çıkışının irdelendiği görülecektir. Bu nedenle de başlı̆̆ın "Batı Avrupa'da hürriyeti bağlayıcı cezaların ortaya çıkışında etkili olan koşullar" olarak belirlenmesinin daha uygun olduğu ve mevcut başlığın içerikle tam örtüşmediği düşünülebilir. Ancak metin içerisinde de aktarıldığı üzere, örgütlü hapishanenin ilk ortaya çıktı̆̆ı yer Batı Avrupa'dır. Zamanla bu yeni cezalandırma biçimi diğer Avrupa devletlerine ve Tanzimat'tan sonraki süreçte de Osmanlı Devletine aktarılmıştır. Bu bağlamda hürriyeti bağlayıcı cezaların ortaya çıkışı aktarılırken, ayrıca Batı Avrupa vurgusunun yapılması gerekliliği hissedilmemiş̧ir. Çünkü örgütlü hapishane ilk burada ortaya çıktığından, bu oluşuma etkili olan koşullar irdelenirken, Batı Avrupa üzerinden anlatımda bulunulması zorunluluğu aşikârdır.

\section{Modernizm Kavramı}

Modernizm, özellikle 17. yüzyılın ikinci yarısından itibaren görülmeye başlanan, aydınlanmanın ve sanayileşmenin şekil verdiği düşünsel ve toplumsal düzen olarak ifade edilebilir. Bu süreç, yeni toplumsal yaşam ve örgütlenme biçimi olarak 17. yüzyılda, Avrupa'da ortaya çıkmış ve buradan neredeyse tüm dünyaya yayıllmıştır. ${ }^{8}$ Halen modern sürecin içinde olduğumuza dair görüşler bulunmakla birlikte, 1900’lü yılların ikinci yarısından itibaren daha çok "postmodern dönem" olarak nitelendirilen yeni bir döneme geçildiği hususunda da görüşler bulunmaktadır.9

Modern çağ, insanoğlunun büyük başarılarına ev sahibi olmuştur. Aydınlanma düşüncesi bilimin önünü açmış, fen bilimleri alanındaki gelişmeler sanayi alanındaki büyük atılımları tetiklemiş, kültür ve sanat alanında yeni türler ve akımlar ortaya çıkmıştır. Bununla birlikte modernizm insanlık adına büyük acıların da yaşandığı bir dönem olmuştur. Kapitalist dönüşüm bir dünya sistemi haline gelirken; emekçiler, kadınlar, üçüncü dünya halkları büyük acıların muhatabı olmuşlardır. Modernizmin en büyük

8 Anthony Giddens, Modernliğin Sonuçlarl (Ayrıntı Yayınları, İstanbul 2018) 18.

9 Hakan Karakehya, 'Modern Cezalandırma Sistemlerinin Büyük Anlatıları' (2008) 66 (1) İstanbul Üniversitesi Hukuk Fakültesi Mecmuası 88. Buna karşın, ikinci dünya savaşından sonra, dünyayı modernliğin de ötesine götüren yeni bir sürecin başladığı da ileri sürülmektedir. Yeni bir sürecin içinde olduğumuzu ileri süren yazarların önemli bir kesimi ise, bu süreci postmodern dönem olarak adlandırmaktadırlar. Postmodern kavramının içeriği konusunda ayrıntılı bilgi için bkz. Jean François Lyotard, Postmodern Durum (Vadi Yayınları, Ankara 2000) 144 vd. 
ahlâk normu söylem boyutunda hümanizm iken gerçekte modernizmin ikinci bir yüzü olduğu da görülür. Nitekim bu aydınlık çağ, aslında karanlık olan bir diğer yönüyle, baskı altına alma ve disipline etme çağıdır. ${ }^{10}$

Esasında modernleşme süreci 16. yüzyılda başlayıp günümüze kadar devam eden kapitalizme dönüşme süreci ile de kesişmektedir. ${ }^{11}$ Fabrika üretimine geçiş öncesinde ticari nitelikte olan kapitalizme dönüşme süreci bu evrede sınaî bir boyut ve nitelik kazanmıştır. ${ }^{12} \mathrm{Bu}$ sürecin belli bazı yapıtaşları bulunmaktadır. Katoliklik reformasyon yoluyla akla uygun bir biçimde yorumlanmış, dinsel kozmolojinin yerini bilim almış, yaşama ekonomi egemen olmuş, kentler ön plana çıkmış, monarşi ve oligarşiler yıkılarak siyasal sistemler demokratikleşmeye başlamış ve ulusal/sınıfsal yeni türden kimlikler toplumsal bütünleşmede belirleyici rol oynamaya başlamıştır. ${ }^{13}$

Modern dönemde toplum kendi meşruiyetini herhangi bir dış otorite olmaksızın kendi ürettiği ilkelere dayandırmaya başlamıştır. ${ }^{14} \mathrm{Bu}$ ilkeler bilim yoluyla üretilmektedir. ${ }^{15}$ $\mathrm{Bu}$ anlamda modern dönemde, toplumsal düzenin, modern öncesi dönemde meşruiyetini aldığı bazı geleneksel yapılar değerini kaybetmeye ve meşruiyet kaynağı olma özelliklerini yitirmeye başlamışlardır. Bu bağlamda Bauman'ın “akışkan modernite” kavramından da bahsetmek gerekir. Bauman, postmodern süreç olarak da ifade edilen 20. yüzyllın ikinci yarısından itibaren yaşanan değişim sürecini, "akışkan modernite" olarak nitelendirmektedir. Akışkan tanımlaması toplumsal olarak kabul edilmiş genel-geçer kuralların olmayışı anlamına gelmektedir. Yani Bauman'a göre postmodern dönem, toplumsal yapının "katı" bileşenleri olarak kabul edilebilecek dini ve geleneksel kuralları yok saymakta; bir nevi onları "akışkan"laştırmaktadır. Nitekim gerçekten postmodern dönemde göreceli bir doğru anlayışı hâkim olmuş ve bu durum kuralların toplumsal düzeyde uygulanışını anlamsız hale getirmiştir. Bununla birlikte Bauman, modernizmin

10 Foucault (n 5) 325.

11 Bu bağlamda modern süreci, toplumsal sonuçları bakımından üç alt safhaya ayırarak inceleyen yazarlar bulunmaktadır. Örneğin Özcan'a göre bunlardan birincisi ticaretin ortaçağ tarım ekonomisini değişikliğe uğratması olarak erken modernlik safhası, ikincisi belirgin şekilde kendisini sanayi devrimiyle açı̆̆a vuran kapitalist toplumun tipik özelliklere büründügü yüksek modernlik safhası ve üçüncüsü kapitalizmin tekelci bir aşamaya ulaşmasıyla gelişen bir toplumsal formasyon olarak kitle toplumu safhasıdır. Mehmet Tevfik Özcan, Modern Toplum ve Hukuk Devleti (XII Levha Yayınları, İstanbul 2008) 50 vd.

12 Aylin Yonca Gençoğlu, 'Ticari Kapitalizmden Sanayi Kapitalizmine: Merkantalizm, Liberalizm ve Marksizm' (2013) 7 (14) Toplum Bilimleri Dergisi 86.

13 Gencay Şaylan, Postmodernizm (İmge Kitabevi, Ankara 2016) 73, 74.

14 Bu bağlamda örneğin bilim, bilginin tek kaynağı olarak görülmeye başlanmış, modern öncesi dönemlerde toplum içerisinde geçerliliği kabul edilen teolojik ya da metafiziksel bilgiler tamamen yadsınmıştır. Bu konuda ayrica bkz. Karakehya (n 9) 89 vd.

15 Şaylan (n 13) 73, 136. 
de en başından beri aslında katıları akışkanlaştırma yani gelenekten kurtulma süreci olduğunu ileri sürer. Modernizm, tek ve evrensel bir gerçek olduğunu öne sürmektedir. Bu gerçeğe ise ancak kutsal olanın dünyevileşmesi, gelenek egemenliğine son verilmesi, tüm inanç ve bağl1lıklardan kurtulunması yoluyla ulaşılabilecektir. ${ }^{16}$ Bununla birlikte modernizm, kurtulduğu gelenek, inanç ve bağlılıkların yerine, yeni ve daha gelişmiş kurallar koymak hususunda da oldukça istekli ve kararlıdır. Kısacası postmodernizmin problemi tüm toplumsal kurallar iken modernizmin problemi kendisinden hemen önceki dönemin kurallarıdır. Postmodernizm mutlak doğruyu ve dolayısıyla tüm kural ve gelenekleri reddeder ve yine insanoğlunun mutlak doğruya ulaşmasının mümkün olmadığ düşüncesinden hareketle, reddettiği gelenek ya da kuralların yerine yenilerini koyma gibi bir istek ya da çaba da göstermez. Modernizmin geçmiş kuralları kaldırarak yerine yeni kurallar koyma isteğinin altında ise aydınlanma düşüncesinden kaynaklanan, zaman içinde değişme ihtiyacı duyulmayacak, dünyayı daha öngörülebilir hale getirecek yeni kurallar bulma ve üretme isteği ile bunun gerçekleşebileceğine olan inanç yatmaktadır. ${ }^{17}$ Modernizme göre hareketi kısıtlayan ve girişimleri engelleyen kurallar terk edilmelidir. Bu terk ediş, en başta ekonomik ilişkileri, kendilerine ayak bağı olan ev-aile ilişkilerinden ve etik sorumluluklardan kurtarma anlamına gelmektedir. ${ }^{18}$ Mali kaynakların kapitalizme uygun bir biçimde kullanılmasına engel olan birtakım bağlılıklardan kurtulunması ve yerine buna elverişli yeni kuralların ihdas edilmesi gerekmektedir. Nitekim bu dönemde Hristiyanlık'ta bir reform hareketi başlamış ve Protestanlık mezhebi ortaya çıkmıştır. Protestanlık mezhebi kilisenin uygulayageldiği gelenekleri terk etme yoluna gitmiştir. ${ }^{19}$

Terk edilen kuralların yerine yenilerinin tesis edilebilmesi için bireyler üzerinde daha çok müdahaleye ve gözetime ihtiyaç bulunmaktadır. Bu bağlamda modern devletin toplumsal

16 Zygmunt Bauman, Akışkan Modernite (Can Sanat Yayınları, İstanbul 2017) 27. Bu durumun en belirgin örneklerinden birini, modern dönemde araçsal aklın toplumsal yaşama hâkim kılınması oluşturur. Nitekim modern dönemin yeni anlayışına göre "akılcı olan faydalı olandır.” Bu durumu Horkheimer şu şekilde ortaya koyar: "sıradan bir insana akıl teriminin anlamını açıklamasını isteyin, hemen her zaman bir duraksamayla sıkıntılı bir çaresizlikle karşılaşırsınız... gene de cevap vermek için sıkıştırıldığında, akla uygun şeylerin yararlı şeyler olduğunu ve her akla uygun insanın da kendisine neyin yararlı olduğunu bilmesi gerektiğini söyleyecektir... Bu akıl tanımı ne kadar masum ya da yüzeysel görünürse görünsün, batı düşüncesinde son yüzyıllarda meydana gelen derin bir değişmenin belirtisidir.” Max Horkheimer, Akll Tutulması (Metis Yayınları, İstanbul 2005) $54 \mathrm{vd.}$

17 Modern düşüncede bilim sayesinde insanlık için en iyi olan tespit edilecek, bu en iyi olana ulaşmak için bilimsel yöntemler geliştirilecek, amaçların gerçekleştirilmesiyle de küresel çapta mutluluk ve refah sağlanacaktır. Dolayısıyla modern düşüncede, akılcı olan ve deneysel bilgiye dayanan faydalı olandır, düşüncesi hâkimdir. Karakehya (n 9) 90.

18 Bauman(n 16)27.

19 Max Weber'in, kapitalizmin gelişimini protestan ahlâkının yaygınlaşmasına bağladığı eseri için bkz. Max Weber, Protestan Ahlakı ve Kapitalizmin Ruhu (Ayraç Yayınevi, Ankara 1999) 133-158. 
hayatın her alanına müdahale ettiği, müdahale ettiği bu alana ilişkin kural ve standartlar getirdiği, bunlara uymayanlar bakımından ise etkili yaptırımlar öngördüğü gözlenmektedir. Getirilen bu kuralların toplum nezdinde benimsenmesi ve uygulanması müdahale ve gözetim ile mümkün olacaktır. Modernizm, çalışma alanları başta olmak üzere tüm alanlarda yeni ihdas edilen kuralların uygulanmasını hedeflemekte ve bireylerden bu kurallar doğrultusunda öngörülebilir ve tekdüze davranışlar beklemektedir. Modernizm bu nedenle tüm sıra dış1lıkların karşısında durur. Sıra dışılıkların engellenebilmesi için yoğun gözetim gerekmektedir. Gözetim doğrudan ya da dolaylı yoldan gerçekleştirilebilir ve bireyler hakkında bilgi toplanması ve kontrolü üzerine kuruludur. ${ }^{20}$ Ekonomi ve iş hayatında fordizm, bireysel kimliklerin tamamen kapı dışarı bırakıldığı bürokrasi, panoptikonlar ve toplama kampları sıra dış1lıkların karşısında duruşun en önemli araçlarıdır. ${ }^{21}$

Modern sürece hâkim anlayışa göre, insan kendisi ve doğa ile ilgili bilgisini devamlı olarak artıracak; böylelikle doğayı ve doğanın bir parçası olan insanı devamlı insanlığın çıkarı doğrultusunda dönüştürecek ve tarih devamlı olarak ileriye doğru akacaktır. Bu anlayışın modern düşünce akımlarına oldukça iyimser bir karakter kazandırdığı görülmektedir. Modern düşünceye göre insanlık daima iyiye gidecektir. Modern dönemde görülen yoğun anayasacılık hareketlerinin de bu iyimserliğin sonucu olduğu söylenebilir. ${ }^{22}$

Modernizm için bilim oldukça önemli bir konumdadır. İnsanın akıl ve bilim yoluyla giderek evrene hâkim olacağı, toplumu akla uygun olarak düzenleyeceği ve nihayetinde ideal bir düzen ortaya koyacağına inanılmaktadır. Bu inanç modern dönemde bilhassa entelektüel kesimin bir "yasa koyucu” rolü benimsemesine ve yukarıda söz edildiği gibi modern çağda terk edilen gelenek ve kuralların yerine yenisinin koyulması hususunda büyük bir istek ve hatta sorumluluk duyulmasına yol açmıştır. ${ }^{23} \mathrm{Bu}$ dönemde hukuk da modernleşmeden etkilenmekle birlikte aynı zamanda modernleşmenin bir aracı olarak da kullanılmış; araçsal bir hale dönüşmüştür. ${ }^{24}$

20 Giddens (n 8) 62.

21 Bauman (n 16) 54-55.

22 Şaylan (n 13) 20, 74. Bu bağlamda 19. yüzyılda toplumsal ve politik yaşamın merkezinde bulunan yaklaşımlardan birisi de "evrimci teori”"dir. Bu teoriye göre; toplumlar değişmek ve gelişmek zorundadır. Bir toplumun değişmesi kaçınılmazdır ve değişimin olduğu yerde ise her zaman için gelişim, yani pozitif bir hareketlilik vardır. (Evolutionism Maddesi) Gordon Marshall, 'Evolutionism', Oxford Dictionary of Sociology (Oxford University Press, New York 1998) 208.

23 Bauman'ın entelektüel rol üzerinden modernizm ve postmodernizmi yorumladığı eseri için bkz. Zygmunt Bauman, Yasa Koyucular ile Yorumcular (Metis Yayınları, İstanbul 2017) 11.

24 Metin Türkmen, Modernleşme ve Hukuk Türkiye’de Ceza Adalet Sistemi ve Denetimli Serbestlik (Doğu Kitabevi, İstanbul 2018) 109-111. 


\section{Modern Sürecin Temel Unsurları}

\subsection{Genel Olarak}

Modern sürecin temel unsurları ve modern dönemin karakteristiği hususunda pek çok farklı görüş ileri sürülmüş olsa da çalışmamızda modern sürecin temel unsurları; sanayileşme, sanatsal-kültürel değişim ve aydınlanma üzerinden incelenecektir. Gerçekten de başkaca bir takım özellikleri olsa da modern sürecin bu üç önemli sacayağ üzerine inşa edildiği söylenebilir. ${ }^{25} \mathrm{Bu}$ başlikta bu üç temel unsur incelendikten sonra, bir sonraki başlıkta modern sürecin kamusal cezalandırmaya etkili alt unsurları ele alınacaktır. Modern sürecin unsurlarını bu şekilde temel unsurlar ve cezalandırmaya etkili diğer unsurlar diye ayırarak incelememizin sebebi, modern sürecin kamusal cezalandırmaya etkisini incelerken, aynı zamanda modern sürecin temel esaslarına ilişkin bir bakış açısı oluşturma amacında olmamızdır. Nitekim modern süreç temel unsurları bakımından net olarak anlaşılmadıkça, kamusal cezalandırmanın hangi koşullar altında değişime uğradığını belirlemek de zorlaşacaktır. Bu nedenle temel unsurları ayrıca ele alıp vurgulamak gerektiği kanaatindeyiz.

\subsection{Sanayileşme}

Modernizmin en önemli belirleyici unsurlarından biri sanayileşmedir. Sanayileşme makinelerin merkezi rol oynadığı, cansız maddi güç kaynaklarının mal üretiminde kullanımını ifade eder. ${ }^{26}$ Gerçekten sanayileşme ile birlikte makineler ile yapılan üretim insan eli ile yapılan üretimin yerini almıştır. Güç kaynağı olarak insan ve hayvanlar yerine su ve buhar gücü kullanılmaya başlanmış; sanayi devrimini başlatan mekanik çıkrık ve dokuma makinelerinin kullanımı ile birlikte deniz aşırı ticarete yönelinmiş ve bu durum da yeni teknolojik gelişmelere öncülük etmiştir. ${ }^{27}$ Sanayileşme süreci 18. yüzyılda zirvesine ulaşmış ve bu yüzyılda sanayi devrimi meydana gelmiştir. ${ }^{28}$ Sanayi devriminin 1700'lerin ikinci yarısında İngiltere'de gerçekleştiği kabul edilir. Devrim İngiltere'den başlayarak önce tüm Avrupa'ya sonrasında ise dünyaya yayılmıştır. ${ }^{29}$

Modernizm bir donanım çağı olarak ifade edilir. Nitekim mekânı; büyük makineler, büyük alanlara yayılan fabrikalar ve çok sayıda işçiyle fethetmek ve mülkiyeti bu

25 Hakan Karakehya, 'Tanzimat Sonrası Osmanlı Devletinin Kamusal Cezalandırma Sisteminde Yaşanan Değişim', Prof. Dr. Nevzat Toroslu’ya Armağan (Ankara Üniversitesi Yayınları, Ankara 2015) 575.

26 Giddens (n 8) 60.

27 Georg Fulberth, Kapitalizmin Kisa Tarihi (Yordam Kitap, İstanbul 2011) 149.

28 Gülten Kazgan, İktisadi Düşünce veya Politik İktisadın Evrimi (Remzi Kitabevi, İstanbul 2000) 70.

29 Durmuş Günay, 'Sanayi ve Sanayi Tarihi' (2002) (31) Mimar ve Mühendis Dergisi 1. 
şekilde sahiplenmek erken modernizmin en zorlayıcı arzusu olarak karşımıza çıkmaktadır. Zenginlik ve iktidar, kömür ve demir gibi mekâna bağlı şeyler ile ilişkilidir. ${ }^{30}$ Şüphesiz modernizmin bir donanım çağı olmasında sanayi devriminin etkileri büyüktür. Sanayi devriminin başlarında üretim mekâna bağlı büyük makineler ile ve yine mekâna bağlı hammaddelerle gerçekleştirilmektedir.

Fabrikaların büyük alanlara yayılmasının sonucu olarak iş yeri / konut ayrımı ortaya çıkmıştır. Nitekim sanayi devrimi öncesinde tarımsal üretim de zanaat üretimi de üreticilerin konutlarının yakınında yer alan üretim alanlarında gerçekleştirilmektedir. İş yeri / konut ayrımı ile birlikte kentler gelişmiş ve kent toplumu ortaya çıkmıştır. İşçiler sabah konut alanlarından iş yerlerine seyahat etmeye başlamış ve bu durum ulaşım hareketliliğinin yoğunlaşmasına neden olmuştur. ${ }^{31}$ Sanayi alanları eski kentlerin dışında, enerji kaynakları, ulaşım imkânları, insan kaynağı ve hammaddenin sunumunun ucuz ve kolay olduğu yerlerde kurulmuştur. Üretim etkinlikleri buhar gücünün de etkisi ile belirli bölgelerde yoğunlaşmış ve yönetim hizmetleri de bu bölgelerin etrafinda birikmiştir. Böylelikle bu bölgelerin etrafinda işçi kentleri kurulmuş ve kentleşme ortaya çımaya başlamıştır. ${ }^{32} 19$. yüzyılın başlarında nüfusun önemli bir çoğunluğu sanayide çalışmaya başlamış, tarımda da makineleşmenin gerçekleşmesi ile birlikte küçük toprak sahipleri topraklarını satarak kentlere göç etmiştir. Kentlere doğru hızlı bir biçimde gerçekleşen bu göç, kentlerde bazı alt yapı sorunlarının meydana gelmesine neden olmuştur.

Bu sırada kapitalizm de 16. yüzyıldan itibaren Kuzeybatı Avrupa'da kendini göstermeye başlamış 19. yüzyıla gelindiğinde ise sanayi devrimi ile olgunlaşarak yeni bir aşamaya girmiştir. 19. yüzyılın ikinci yarısından itibaren yaygın toplumsal düzen sanayileşmiş kent toplumu olarak karşımıza çıkar. Emeğini kiralayarak yaşamını sürdüren emekçi kesim de bu aşamada ortaya çıkmaktadır. ${ }^{33}$ Sanayileşme ile birlikte emek ve emeğin kaynağı olan beden önem kazanmıştır. Bunun yanında bedenden maksimum faydanın sağlanması amaçlanmış ve bu durum sanayi toplumuna uygun mekanik bireyler oluşturulması amacını ortaya çıkarmıştır.

\subsection{Sanatsal ve Kültürel Değiş̧im}

Modernizm kavramı sanat alanında, 19. yüzyılın sonlarında ortaya çıkıp giderek hakim bir duruma gelen belli bir sanatsal estetik anlayışını ifade etmektedir. Bu estetik anlayış

30 Bauman (n 16) 173.

31 Günay (n 29) 1.

32 Ruşen Keleş, Kentleşme Politikası (İmge Kitabevi, Ankara 2016) 37, 44.

33 Şaylan (n 13) 9. 
toplumun sanayileşmesi sürecinde oluşmuştur ve "modern sanat" olarak ifade edilir. ${ }^{34}$ Modern dönemde sanatsal ve kültürel değişim konusunu incelerken iki ayrı kavram kullanmak faydalı olacaktır. Bunlardan ilki yukarıda söz edilen "modern sanat" kavramıdır. İkinci kavram ise "modernizm dönemi sanatı" olarak adlandırılabileceğimiz 17. yüzyıldan 20. yüzyıla kadar süren modernleşme sürecindeki sanat anlayışını ifade etmektedir.

Modernizm öncesinde Tanrı'nın yüceliğini anlatmak üzerine şekillenen estetik anlayışı, modernizm sürecinde Rönesans ile realizm ilkesi çerçevesinde şekillenmeye başlamıştır. Sanattaki realizm akımında gerçek aranır ve sanat yoluyla ifade edilir. Modernizm öncesi dönemdekinin aksine gerçek arıtılmaz, kuvvetlendirilmez ve olduğu haliyle ifade edilir. ${ }^{35}$ Aydınlanmanın temel argümanı olan akıl ve bilimin üstünlüğü ve gerçekliğin akıl ve bilimle kavranabileceği düşüncesi sanata da yansımıştır. Sanatçının eseri ile estetik bir değer ortaya koyabilmesi için akıl ve bilim ile kavranabilecek gerçekliği başarı ile yansıtması gerekmektedir. Bu nedenle anatomi bilgisi ve perspektif gibi hususlar Rönesans dönemi sanatı için oldukça önemlidir. Yalnızca görsel sanatlarda değil edebiyatta ve müzikte de realizmin etkileri görülmüştür. Edebiyatta insana özgü gerçek sorunlar ve durumlar anlatılmış; müzikte ise doğayı anlatan ve insan algısını harekete geçirmesi beklenen pek çok eser verilmiştir. Tüm bu alanlarda icra edilen sanat için "klasik" tabiri kullanılmıştır ve klasik sanat estetiği, evrensel ve nesnel olduğu kabul edilen gerçekliği tanımlamak üzerine kuruludur. Modernizm dönemi sanat anlayışında geçmişi kutsamak reddedilmiş; akıl ve bilim üzerine bugünü ve geleceği kurmaya ehemmiyet verilmiştir. ${ }^{36}$ $\mathrm{Bu}$ dönemde sanat türü fark etmeksizin sanatçlların, eserlerinde yaşanan gerçek toplumsal olayları yansıttığı görülmektedir. ${ }^{37}$ Toplumsal gerçekliğin bu denli yansıtılması da realizmin bir gerçekleşme biçimi olarak değerlendirilebilir. Yine bu dönemde hümanizm düşüncesi neticesinde bedene ve bedenin estetiğine önem verilmeye başlamış ve bu durum bilhassa görsel sanatlarda beden uyumu ve güzelliğin oldukça önemli hale gelmesine neden olmuştur. ${ }^{38}$

Öte yandan bilhassa modern dönemin başlangıcında Katolik Kilisesi de Protestan reformasyonu ile sanat aracılığgyla fikirlerini tekrar güçlü bir şekilde yayarak mücadele etmeyi denemiş ve yeni dini coşkuların duyulmasını sağlamak üzere pek çok sanat eserinin yapılmasına önayak olmuştur. ${ }^{39}$

34 Şaylan (n 13) 80.

35 Adnan Turani, Dünya Sanat Tarihi (Remzi Kitabevi, İstanbul 2013) 513.

36 Şaylan (n 13) 81-85, 132.

37 Eric Hobsbawm, Devrim Çağı (Dost Kitabevi, Ankara 2013) 277.

38 Boğos Zekiyan, Hümanizm (İnsancıllk) Düşünsel Iç̧lem ve Tarihsel Kökenler (İnkılap Kitabevi, İstanbul 2005) 46.

39 Stephen Farthing, Sanatın Tüm Öyküsü (Hayalperest Yayınevi, İstanbul 2012) 212, 213. 
Bu dönemde kapitalizmin gelişmesi ve sanayi devrimi ile sanat ürünleri de metalaşmaya başlamış, sanatçı sanat alanındaki varlığını sürdürebilmek için diğer sanatçılar ile rekabet haline girmiş ve bu rekabet özgünlük ihtiyacını da beraberinde getirmiştir. $\mathrm{Bu}$ özgünlük ihtiyacının da etkisiyle, 19. yüzyılın sonlarına doğru ortaya çıkmaya başlayan ve "modern sanat" adı verilen akım, klasik sanatın gerçekçi yaklaşımını yadsımıştır. $\mathrm{Bu}$ akıma göre realist ve yansımacı estetik pasiftir ve sanatçıya sanatında hareket alanı tanımamaktadır. ${ }^{40}$ Kavramsal olarak "modern sanat" olarak tanımlanan sanat akımının estetik anlayışı da gerçekliğin yansıtılması üzerine kuruludur. Fakat bu gerçeklik evrensel gerçeklikten ziyade sanatçının kendi düşünce ve duygu dünyasında algıladığ 1 gerçekliktir. Sanatçı gerçekliği olduğu hali ile değil geçip giden andan kendisinde kalan izlenim aracıllı̆ı ile aktarmaktadır. ${ }^{41}$

Modernizm döneminin sanat ve kültüründe aydınlanma felsefesi belirleyici bir konumdadır. Kültür ve devlet arasında da kuvvetli bir bağlantı vardır. Akıl ve bilime dayanan kültürün halka benimsetilmesinin, modernizmin çıktılarından sayılan ulus devletin ana işlevlerinden biri olduğu kabul edilir. Bu kültür, akıl ve bilime dayanması nedeniyle "yüksek" olarak da kabul edilmektedir. Yüksek kültürün topluma benimsetilmesi sorumluluğu devlet ile birlikte aydınlara da verilmiştir. ${ }^{42}$

\subsection{Aydınlanma}

Aydınlanma, Batı Avrupa'da 17. ve 18. yüzyıllarda ortaya çıkmış düşünsel akım olarak ifade edilebilir. Aydınlanma düşüncesi kapitalist dönüşüm ve dolayısıyla modernleşme sürecinde ortaya çıkmıştır. Bu bağlamda aydınlanma; modern sürecin belirli bir dönemine hâkim olan düşünme biçimini, bu büyük ve total dönüşümün kültürel özelliklerini ifade eder. ${ }^{43}$ Ancak aydınlanmanın asıl etkisi, kamusal faaliyetlere ve hatta büyük oranda bireysel yaşama akıl yoluyla elde edilen bilimsel bilginin hâkim kılınmasında görülür. ${ }^{44}$

Aydınlanma felsefesine göre insanlık, akılcılık ve iyimserlik aracılığıyla tarihin ileriye akışını hızlandırabilecek ve bunu gerçekleştirme hususunda gönüllü olacaktır. Özgürlük, eşitlik, hümanizm aydınlanmanın temel değerleridir. ${ }^{45}$ Aydınlanmanın temel değeri

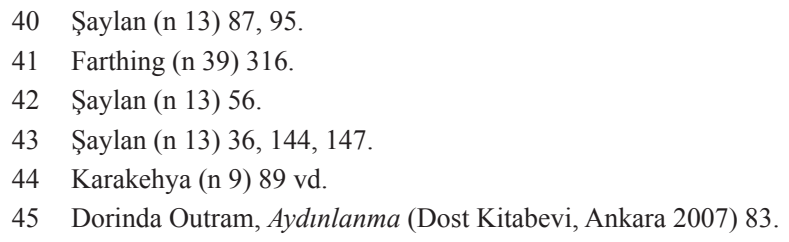


olarak söz ettiğimiz özgürlüğün tanımı yine akılcılığa dayanmaktadır. Modern dönemin özgürlüğü, postmodern dönemin özgürlük tanımının aksine haz odaklı değil akılcılık odaklıdır. İnsanın akılcı davrandığı oranda özgür olacağı iddia edilir. Bu tanım insanoğlunun kendisini belli ölçüde sınırlamasını da gerektirmektedir. ${ }^{46}$ Kant, “Aydınlanma Nedir?” sorusuna verdiği meşhur cevapta aydınlanmayı yabancı bir yönlendirmeye bağlı kalmadan kendi aklını kullanmak olarak tarif eder ve insanoğlunun o döneme kadar kendi aklını kullanma şansı ve isteği olmadığından üzüntü ile bahseder. Bununla beraber aklın kamuoyu önünde ve kamu yararına açık bir biçimde kullanılmasının kesinlikle sınırlanmaması gerektiğinden söz ederken diğer bir yandan ise aklın özel kullanımının sınırlandırılabileceğinden bahseder. Kant'a göre aklın kamusal kullanımından kasıt bir kimsenin düşüncesini kamu ile onlara faydalı olması düşüncesiyle paylaşması iken; aklın özel kullanımı kişinin kendi işi çerçevesinde kendisine teslim edilen kamusal bir hizmeti yerine getirmesidir. İkincisinde akıl kullanımı sınırlandırılmalı, itaat esas olmalıdır. Bireyin kamusal nitelikli bir görevini yerine getirirken itaatkâr olma yükümlülüğü bulunur. Fakat bu kamusal göreve ilişkin eleştirel düşünceleri mevcutsa; bu düşünceleri dile getirme konusunda da mümkün olduğunca özgür olması gerekmektedir. Nitekim eleştirilerini kitle karşısında dile getirmesi aklın kamusal kullanımıdır. Kant'ın bu aydınlanma tanımından; aydınlanma sürecinin, iktidarın "Düşünme itaat et!" yaklaşımından "İtaat et ve istediğin kadar düşün!” yaklaşımına yönelmesi olduğu sonucuna varılmaktadır. ${ }^{47}$ “Aydınlanma nedir?" sorusuna aydınlanmacı bir düşünür tarafindan verilen bu cevap bireylerin bir yandan titizlikle itaat ederlerken diğer bir yandan nasıl özgürce düşünmeye cesaret edebileceklerine net bir cevabı olmaması bakımından eleştirilmiştir. ${ }^{48}$

Aydınlanma düşüncesine göre insanoğlu akıl ve bilim yoluyla doğaya hakim olarak özgürleşecektir. İnsanoğlunun doğaya hakim olması ona baskı kurması anlamına gelmektedir. Bu düşünce bir nesneye herhangi bir şekilde baskı kurma yoluyla özgürleşmenin mümkün olmayacağı bakımından eleştirilmiştir. Ayrıca doğa üzerinde baskı kurma isteğinin insan üzerinde baskı kurmaya da dönüşebileceği değerlendirilmiştir. İnsanoğlunun, insan üzerinde baskı kurması araçsal akıl ile mümkün olmaktadır. Araçsal akıl, aklın; amacı sorgulamak için değil yalnızca belirlenen amaca götürecek en doğru yolların tespit edilmesi için kullanılmasını ifade eder. Modernizm özelinde

\footnotetext{
46 Şaylan (n 13) 41, 57, 123.

47 Immanuel Kant, Aydinlanma Nedir? < https://www.istabip.org.tr/site_icerik/2017/haberler/kasim/aydinlanma nedir_kant.pdf $>$ accessed 13 June 20192.

Michel Foucault, 'Aydınlanma Nedir?' (2005) 10 (38-39) Liberal Düşünce 235.
} 
amaç, doğaya hükmetmektir. Doğaya hükmetmenin ne kadar rasyonel olduğu sorgulanmaksızın doğaya ne şekilde hükmedilebileceği hususu üzerine odaklanılır. Doğaya hükmetmek için yukarıda da söz edildiği gibi, onun bir parçası olan insana da hükmedilmesi gerekmektedir. Yine kimi düşünürler aydınlanma felsefesinin kendini koruma içgüdüsüne dayalı bir akıl kullanımını ifade ettiğini söylemektedir. Böyle bir durumda akıl, araçsal bir konuma indirgenecek ve araçsal akıl herhangi bir etik değer gözetmeksizin kendini koruma içgüdüsü ile şiddete ve teröre yönelebilecektir. ${ }^{49}$ Nitekim insanlık modern dönemde bu türden pek çok kıyıma tanıklık etmiştir.

Aydınlanma düşüncesi insanoğlunun bilim aracıllğıyla her tür sorunu çözebileceği ve böylelikle neredeyse dünyada cennetin yaşanacağ 1 düşüncesini temel almaktadır. Aydınlanma felsefesi gerçeğe akıl ve bilim yoluyla ulaşllabileceğini ve bu bilginin akıl ve bilim yoluyla ulaşılması dolayısıyla evrensel olduğunu ifade eder. ${ }^{50}$ Aydınlanma felsefesine göre bilgi kadar ahlâk ve hukuk normları da evrenseldir. Toplum için olması gereken kuralların akıl ve bilim yoluyla tespit edilebileceği ve aynı şekilde bu kuralların da evrensel olacağı iddia edilmiştir. ${ }^{51}$ Aydınlanma felsefesi yaşamı, bilimin yol göstericiliği ve akıl ile yeniden kurgulamak gerektiğini söyler.

Aydınlanmanın amacı insanın özgürleşmesi ve yücelmesidir. Bu amaca ulaşmak için de insanların akla uygun davranması gerekmektedir. Bu bakımdan özgürlüğe ulaşma amacı yolunda insan da araç konumuna gelmektedir. ${ }^{52}$ Kant'ın aydınlanma tanımında aklın kamusal kullanımı için örnek verilirken "bir bilginin, bilgisini ya da düşüncesini yani aklını, onu izleyenlere, okuyanlara yararl olacak bir biçimde sunması" örneğinin verildiği; düşüncesini sunan kişi için "bilgin" vurgusu yapıldığ 1 görülmektedir. ${ }^{53}$ Kant ile aynı dönemde “Aydınlanma Nedir?" sorusunu cevaplayan Moses Mendelsshon'ın da aydınlanmayı "insan aklının kullanımına ilişkin henüz tamamlanmamış ve herkese açık olması gereken eğitim süreci” olarak tanımladığı görülür. ${ }^{54}$ Bu durum aydınlanmanın seçkinci bir yapısı

49 Şaylan (n 13) 159, 161.

50 "Modernizmin en önemli özelliklerinden birisi umutvar bir süreç olması ve tüm insanlık için mutluluk getirecek büyük projeler üretmesidir. Bu büyük projeler büyük anlatılara dayanır. Büyük anlatılar ise en azından söylem olarak bilimsel verilerle ortaya konulan ve büyük projelerin düşünsel temelini oluşturan sosyal teorileri ifade eder. Örneğin, sadece gözlem ve deneye dayanan bilginin dünyayı mutluluk ve refaha götürebileceği düşüncesi, pozitivizmin bir büyük anlatısıdır. Bu büyük anlatılar kendilerine tezat oluşturan ve kendilerini yanlışlayan alt anlatıları her zaman için dışlar ve kabul etmezler. Bunu yaparken de modernizmin büyük anlatıları "çünkü ben bilimselim" argümanından güç alırlar." Karakehya (n 9) 94.

51 Evrensellik vurgusu için bakınız. Kant (n 46) 3.

52 Şaylan (n 13) 58, 134, 163.

53 Kant (n 47) 2.

54 Outram (n 45) 18. 
olduğunu düşündürmektedir. Neyin doğal, akla yatkın ya da iyi olduğunu bazı kimselerin diğerlerinden daha iyi bildiği kabul edilmektedir ve daha iyi bilenler diğerlerinin de kendilerinin bulunduğu aşamaya gelmesi için rehberlik edeceklerdir. Bu aşamaya kadar ise modernliğin tam üyelik hakkı sadece daha iyi bilenlere aittir. ${ }^{55}$ Gerçekten insanın akıl ve bilim yoluyla özgürleşmesi beklenmektedir fakat bir yandan da o zamana kadar insanların, aklını yabancı bir yönlendirme olmaksızın kullanmayı hiç tecrübe etmediğinden söz edilmektedir. Bu durum, o zamana kadar kendi aklını hiç kullanmamış ve bilim ile hiçbir teması olmamış kişilerin eğitilmesi gerekliliğini ortaya çıkarır. Gerçekten aydınlanma çağının düşünürleri, insanlığın akıl ve bilim ışığında devam eden özgürlüğe doğru dönüşümlerinin, halihazırda akıl ile iletişim halinde olan ve bu iletişimleri vasıtasıyla gerçeği bilenlerce yönlendirilmesi hususunda hemfikirdir. Yani aydınlanma düşüncesi tarafından halihazırda gerçeği ya da ona nasıl ulaşabileceğini bilen ve azınlık durumunda olan “aydınlanmış" bir kitle olduğu kabul edilir. Toplumun geri kalan kısmının ise bu kitle tarafından aydınlatılması gerekmektedir. Böylelikle onlar da modern dönemin ilkelerini benimseyeceklerdir. Yukarıda da söz edildiği gibi aydınlanma akıl ve bilim yoluyla doğayı kontrol altına almayı ve böylelikle onu öngörülebilir hale getirmeyi planlamaktadır. Halkın "gerçeği ya da ona nasıl ulaşılacağını" bilenler tarafindan eğitilmesi; doğanın bir parçası olan insanın da kontrol altına alınması anlamına gelmektedir. ${ }^{56} \mathrm{Bu}$ durum toplumun çıkarına olan hususların belirli gruplar tarafindan belirlenmesini ve bu çıkarların gerçekleşmesi için toplumdan tek beklenen şeyin disiplin becerisi olması sonucunu doğurur. ${ }^{57} \mathrm{Bu}$ çağ böylelikle yukarıda da söz edildiği gibi bir disipline etme çağı haline gelmekte ve tüm toplumsal kurumlar bu çerçevede gelişmektedir.

Aydınlanmanın bir diğer önemli unsuru ilerlemeci tarih felsefesinin hakim olmasıdır. Aydınlanma felsefesine göre toplum devaml ileriye doğru aşama kaydederek nihai olarak ideal toplum düzenini bulacaktır. Bu dönemde ortaya çıkan tüm akımlar da, ideal tahayyülleri farklı da olsa (Marksizim ve Liberalizm gibi) ideal toplum düzenine yönelmişlerdir. Nihai olarak ideal düzene ulaşılacağı düşüncesi "mutlak gerçeklik" kavramını önemli kılmaktadır. Mutlak gerçeklik ise akıl ve bilim ile ulaşılacak bilginin, zamandan bağımsız ve evrensel olacağına duyulan inanç neticesinde mümkün görünmektedir. ${ }^{58}$

55 Paul Wagner, Modernliğin Sosyolojisi (Ayrıntı Yayınları, İstanbul 2005) 35.

56 Bu bağlamda modern dönemin iktidarlarının bilimsellik vurgusuyla kendilerini temize çıkardığı ve en antidemokratik uygulamalarını bu vurguyla bireylere kabul ettirmeye çalıştığı görülmektedir. Dolayısıyla modern dönemde bilimin aşırı yüceltilmesi, zaman zaman demokratikleşmenin de önünde bir engel oluşturmuştur. Karakehya (n 9) 94 vd.

57 Bauman (n 23) 83, 91 .

58 Şaylan (n 13) $135,145$. 
Son olarak belirtmek gerekir ki; doğal hukuk anlayışı da aydınlanmanın bir sonucu olarak ortaya çıkmıştır. Nitekim doğa aydınlanma döneminde bir etik standart olarak benimsenmiş ve "doğal" olanın iyi olduğu kabul görmeye başlamıştır. ${ }^{59}$ Doğal hukuk anlayışında, bireylerin doğuştan bir takım haklarla birlikte doğdukları düşüncesi hakimdir. Doğal hukuk anlayışını savunan Locke ve Rousseau gibi düşünürler tarafından toplum sözleşmesi teorileri geliştirmiş ve bunun neticesinde cezalandırma yetkisi dayanağını; devletin, tanrısal iradenin dünya üzerindeki temsilcisi olduğu inancından almak yerine bireyler arasında yapılan bir sözleşme ile cezalandırma yetkisinin iktidara verilmiş olması düşüncesinden almaya başlamıştır. ${ }^{60}$ Nitekim Aydınlanma düşünürlerinden olan Beccarria da cezayı, toplum sözleşmesine aykırı davrananların bu davranışını engellemeye yönelik araçlar olarak tanımlamaktadır. ${ }^{61}$

\section{Genel Olarak Modern Sürecin Kamusal Cezalandırmayı Etkileyen Özellikleri ve Bu Özelliklerin Kamusal Cezalandırmayı Etkileme Şekilleri}

Modern süreç üç temel sacayağı üzerine inşa edilmiştir. Bunlar sanayileşme, kültürelsanatsal değişim ve aydınlanmadır. Bu temel unsurlar üzerinden modern sürecin ana hatlarını bir önceki başlıkta ortaya koymuştuk. Burada ise modern sürecin kamusal cezalandırmaya etkili diğer alt unsurları ele alınacaktır. Bu bağlamda modern süreç birçok unsur üzerinden ele alınabilir. Hümanizm, kentleşme, demokratikleşme gibi unsurlar da sıklıkla modern süreç betimlenirken atıfta bulunulan kavramlardır. ${ }^{62}$ Ancak burada tüm bu kavramlara değil; sadece kamusal cezalandırmaya ve dolayısıyla hapishanenin doğuşuna doğrudan etkisi olan alt unsurlara ilişkin bir inceleme gerçekleştirilecektir.

$\mathrm{Bu}$ bağlamda modern sürecin kamusal cezalandırmayı etkileyen temel özellikleri; insanın öneminin artması, bilimselliğin temel değer haline gelmesi ve bilim sayesinde geleceğin daha güzel olacağı inancının yaygınlaşması, disiplin kavramının yaygınlaşması ve gözetimin etkinliğinin anlaşılmasıdır. Aşağıda bu özellikler ayrı başlıklar halinde incelenecektir.

59 Outram (n 45) 120.

60 John Locke, Yönetim Üzerine İkinci İnceleme (Ebabil Yayınları, Ankara 2012) 9. Jean Jacques Rousseau, Toplum Sözleşmesi, (Türkiye İş Bankası Kültür Yayınları, İstanbul, 2006) 13-19.

61 Cesare Beccaria, Suçlar ve Cezalar Hakkında (İmge Kitabevi, Ankara 2016) 25, 26.

62 Wagner (n 55) 22,23. 


\section{5. İnsanın Öneminin Artması}

\subsection{Genel Olarak}

Modern süreçte hürriyeti bağlayıcı cezaların ortaya çıkışını tetikleyen en önemli unsurlardan birisi, kamusal alanda insanın öneminin artmasıdır. Bu bağlamda modern dönemde insanın öneminin artmasını iki ayrı açıdan inceleyebiliriz. Bunlardan ilki insan bedeninin önemli hale gelmesi; ikincisi ise insanın "birey" olma özelliğinin kavranması ve önem kazanmasıdır.

\section{2. İnsan Bedeninin Öneminin Artması}

İnsan bedeninin önemli hale gelmesinde hümanizmin büyük etkileri görülmektedir. $\mathrm{Bu}$ nedenle bu aşamada hümanizme daha yakından bakmak faydalı olacaktır. Aydınlanmanın temel değerlerinden biri olan hümanizm, aydınlanmanın öncüsü olarak kabul edilen Rönesans döneminde Antik Yunan ve Avrupa arasında düşünsel ve kültürel bağın yeniden kurulması ile ortaya çıkmıştır. ${ }^{63}$ Yaklaşık 14. ve 15. yüzyılda İtalya'da ortaya çıkan bu akım daha sonra tüm Avrupa'ya yayılarak kültürel anlamda belirleyici bir karaktere bürünmüştür. Hümanizm insanla bütünleşen bir yaşam ve evren tasavvurunu ifade eder. ${ }^{64}$

Modern öncesi dönemde insan bedeni birtakım geleneksel düşünceler neticesinde önemsiz kabul edilir. Bu duruma ek olarak beden, ekonomik açıdan da modern dönemde taşıyacağı kadar büyük bir önem taşımamaktadır. Modern öncesi dönemde bedenin bu önemsizliğinin, modern öncesi dönem cezalandırma sistemlerinde cezalandırmanın odağında mahkûmun bedeninin bulunmasına elverişli bir zemin hazırladığı öne sürülmüştür. ${ }^{65}$

Modern öncesi dönemde insanın bir bütün olarak kabul edilmediği görülür. Bu şu anlama gelmektedir: insanın bedeni ve ruhu birbirinden ayrıdır ve hatta birbirinin karşısında yer alır. Bu dönemde beden, insanın bu dünyadaki esas amacı olan, ruhunun olgunlaşması yolunda, onu yoldan saptıracak bir tehlike olarak kabul edilmektedir. $\mathrm{Bu}$ düşünce bedenin hor görülmesine neden olmuştur. Hümanizm ile birlikte insan, beden ve ruhtan oluşan bir bütün olarak kabul görmeye başlamış; bedensel zevkler ve çalışmanın gerekliliği gibi hususlar daha görünür ve kabul görür hale gelmiştir. Beden

63 Özgür Küçüktaşdemir, 'Aydınlanma ve Ceza Hukuku' (2014) (113) Türkiye Barolar Birliği Dergisi 60.

64 Zekiyan (n 38) 15, 16.

65 Foucault (n 5) 101-105. 
artık ruhun olgunlaşması yolunda bir ayak bağ değil aksine insanın kendisini gerçekleştirmesine elverişli bir alandır. Ahlak ve erdem anlayışı da bu doğrultuda dönüşür. Artık ahlaki eylemin amacı insan doğasını aşarak doğa ötesi bir kurala uymak değil tam tersine insanın doğasını gerçekleştirmektir. Hümanist düşüncede insanın haysiyeti ve yüceliği de önemli kavramlar olmuş ve bu kavramlar insanın çalışmasına, üretkenliğine ve özgürlüğüne dayandırılmıştır. Hümanist etik, dünya ve doğa gerçekleri içerisinde gerçekleşecek bir ideal olarak kabul edilmiştir. ${ }^{66}$

Şüphesiz aydınlanma düşüncesinin temel değerlerinden olduğu kabul edilen hümanizmin yukarıda açıklanan karakteri modern dönem cezalandırma sistemleri üzerinde etkili olmuştur. Bunun yanında kapitalist dönüşüm ile birlikte insan bedeninin bir üretim gücü olarak daha değerli algılanmaya başlanmasının da modern dönem cezalandırma sistemleri üzerinde etkileri olduğu söylenebilir. Modern dönemde beden artık hem haysiyetli ve yüce insanın bir parçası hem de üretkenliği ile ekonomik düzenin önemli bir bileşendir. Bu yüzden modern dönem cezalandırma sistemlerinde beden, eskiden olduğu kadar hor görülmeyecek ve üretkenliği ön plana çıkaracak şekilde cezalandırılacaktır. Nitekim aydınlanma döneminde cezaların, suçlunun bedenine azap çektirmemesi gerektiğine ilişkin düşünceler yayılmaya başlamıştır. ${ }^{67}$ Bunun yanında, insanın üretken niteliği de göz önünde bulundurulmuş, suçlu kişilerin devlet yararına çalıştırılabileceği fikri ortaya çıkmış ve bu doğrultuda suçlular, deniz donanmalarında küreğe mahkûm edilmeye başlanmış; hatta kendi deniz donanması olmayan devletler tarafından suçlular başka ülkelerin donanmalarına gönderilmiştir. ${ }^{68}$

Modern dönem cezalandırma sistemlerine göre ceza doğrudan bedene yönelmemelidir ve ona zarar vermemelidir. Nitekim o hem bir bütün olarak insanın bir parçası hem de üretim gücüdür. Ancak bir diğer yandan bireyin sslah ve disipline edilmesi için bedenin aracı olarak kullanılması gerekmektedir.

Bilhassa cezaların miktarı ve şiddetinin azalması, cezalandırma alanında hümanizm akımı ile birlikte meydana gelen gelişmeler olarak karşımıza çıkmaktadır. Bu çerçevede

66 Zekiyan (n 38) 44, 47.

67 Aydınlanma Dönemi’nde Beccaria’nın görüşleri cezaların odağına hükümlünün bedeni yerine ruhunun alınması bakımından oldukça etkili olmuştur. Beccaria "Suçlar ve Cezalar" adlı eserinde cezaların, suçlunun bedenini hedef almaması gerektiğinin yanı sıra cezanın işlenen suç ile oranlı olması gerektiği gibi hususlara da değinmiştir. Beccaria’ya göre ceza “insanların ruhları, zihinleri üzerinde pek çok kalıcı ama suçlunun bedeni üzerinde en az üzücü iz bırakacak biçimde” olmalıdır. Cesare Beccaria, Suçlar ve Cezalar Hakkında (n 61) 69-70.

68 Timur Demirbaş, Ceza Hukuku Genel Hükümler (Seçkin Yayıncılık, Ankara 2016) 573. 
1slah edici ve onarıcı adalet yaklaşımı ortaya çıkmaya başlamıştır. ${ }^{69}$ Islah edici adalet anlayışı suçun faili üzerinde yoğunlaşmaktadır ve suçlunun ıslah edilerek topluma uyumlu hale gelmesini amaçlamaktadır. Onarıcı adalet anlayışı ise suç fiilinin neden olduğu kayıpların giderilmesini amaçlar. Bu yaklaşımda suça karşı geliştirilecek tepkiye karar verme sürecine sanık, mağdur ve toplum katılır; bu aktörlerin her birine, suç ile oluşan zararların onarılması için çaba gösterme imkânı sunulur. ${ }^{70}$

Tüm bunların neticesinde hümanizmin, modern cezalandırma sistemlerinin suçluya uygulanacak yaptırımlar ile bu yaptırımlara ilişkin infaz yönteminin, suçlunun yeniden topluma kazandırılmasına yönelik tasarlanışını sağladığı kabul edilir. ${ }^{71}$ Diğer bir yandan hümanizmin, suçluların dönüştürülmesi fikrinin ortaya çıkmasında belirleyici olmadığı; aksine suçluların dönüştürülmesi fikrinin, cezalarda hümanizmin etkisinin görünmeye başlamasına neden olduğu şeklinde görüşler de mevcuttur. ${ }^{72}$

\section{3. Ínsanın Birey Olarak Kabul Edilmesi}

Yukarıda söz edildiği üzere modern dönemde insanın öneminin artması ile ilgili olarak bedenin önem kazanmasının yanındaki diğer husus insanın "birey" olma özelliğinin kavranmasıdır. Gerçekten "birey” kavramı, modern dönemde ortaya çıkıp değer kazanmıştır. Modern öncesi dönemde kalabalıklar içinde kaybolup değersizleşen birey, modern dönemde toplumdan ayrışarak özgürlüğünü ilan etmiştir. ${ }^{73}$ Modern öncesi dönem insanının bir kişilik geliştirmediğinden söz edilir. İnsan yalnızca içine doğduğu sosyal bölümün içerisinde kalmaktadır. Rönesans ile birlikte ise insan kendi kişiliğini aramaya başlamıştır. Yalnızca tek tek insanlar değil; topluluklar da bir benlik geliştirmekte ve bu durum da ulusların ve ulus devletin doğuşunu kolaylaştırmaktadır. ${ }^{74}$ Şüphesiz insanın birey olma özelliğinin kavranmasında da hümanizmin etkileri büyüktür.

Bu bağlamda kalabalıklar içerisinde değersizleşen insandan; özgürlük sahibi, kendi hayatına yön verebilen ve hayat yolunu çizebilen bireye dönüşümün, ceza hukuku ve dolayısıyla kamusal cezalandırma alanında da etkileri olmuştur. İnsanın birey olarak kabul edilişi, genel olarak sosyal ve kültürel alanda insana bakışı değiştirmiş ve kamusal

69 Türkmen (n 24) 68, 69.

70 Vahit Bıçak, Suç Muhakemesi Hukuku (Seçkin Yayıncılık, Ankara 2011) 77, 78.

71 Mehmet Emin Artuk, Ahmet Gökcen and Ahmet Caner Yenidünya, Ceza Hukuku Genel Hükümler (Adalet Yayınevi, Ankara 2012) 15.

72 Halil İbrahim Bahar, 'Hapishaneler, Sorunlar ve Çözüm Arayışları', Hapishane Kitabı (Kitabevi Yayınları, İstanbul 2005) 47.

73 Türkmen (n 24) 105 .

74 Macit Gökberk, Felsefe Tarihi (Remzi Kitabevi, İstanbul 2008) 168. 
faaliyetlerin merkezine insanı koymuştur. Bu dönemle birlikte artık her insanın, nasıl bir suç işlerse işlesin, nasıl bir kişiliğe sahip olursa olsun, sırf insan olma vasfı nedeniyle saygıdeğer olduğu düşüncesi hâkim olmaya başlamıştır. ${ }^{75}$ Sosyal ve kültürel alandaki bu gelişmelerin, cezanın belirlenmesi ve cezalandırma sürecine ilişkin bakış açısını ve uygulamaları etkilememesi de düşünülemezdi. ${ }^{76}$ Nitekim modern dönemin daha başlarında suçluluğun ispatına, cezaların türüne ve infazına ilişkin büyük değişimler olmuş, insanlık adına çok önemli adımlar atılmıştır. Cezalandırma ve cezanın belirlenmesi sürecine ilişkin ilk önemli gelişme cezalandırmanın gayri insani bir toplumsal gösteri olmaktan çıkması şeklinde kendini göstermiştir. ${ }^{77}$ Gerçekten de daha önce büyük kalabalıklar önünde gerçekleştirilen infazlar yerini yavaş yavaş daha insani cezalandırma yöntemlerine bırakmıştır. Bu bağlamda zamanla hürriyeti bağlayıcı cezaların ve dolayısıyla hapishanelerin yaygınlaştı̆̆ı görülmektedir. Ayrıca işkence bir ispat ve cezalandırma aracı olmaktan çıkartılmıştır. ${ }^{78}$ Gelişen süreçte cezalandırmanın amaçları arasında ıslah da yer almaya başlamış, isnat yeteneği olmayanlar için ceza yerine, onların tehlikelilik haline karşı alınan önlemleri ifade eden güvenlik tedbirleri kavramı ortaya konulmuştur. ${ }^{79}$ Cezalandırma sürecine ilişkin yaşanan bu gelişmelerde, Montesquieu, Voltaire, Beccaria gibi aydınlanma dönemi yazarlarının 18. yüzyıldan itibaren ortaya koydukları fikirlerin önemli etkileri olmuştur. ${ }^{80}$ İtalya' da Beccaria, İngiltere' de ise Bentham, daha sonraları klasik okul olarak adlandırılan akım içerisinde, ceza hukuku alanındaki aydınlanmanın öncülüğünü etmişlerdir. ${ }^{81}$

75 Kaldı ki, insan hakları kavramı, insanların sırf insan oldukları için, doğuştan bazı hak ve özgürlüklere sahip olduğu ve devlet tarafından bunlara dokunulamayacağı yolundaki temel düşüncenin bir ürünü olarak, ilk kez bu dönemde geniş kitlelerce dile getirilmeye başlanmıştır. İbrahim Özden Kaboğlu, Dayanışma Hakları (TODAİE Yayınları, Ankara 1996) 1.

76 Tarihsel sürecin de gösterdiği üzere cezalandırma amacının ve cezalandırma metotlarının belirlenmesinde içinde bulunulan dönemin sosyal değerlerinin ve ekonomik yapısının çok önemli bir etkisi vardır. Georg Rusche and Otto Kirscheimer, Punishment and Social Structrue (Transaction Publishers, New Brunswick and London 2003) $3 \mathrm{vd}$.

77 Karakehya (n 9) 91.

78 Aydınlanma öncesi ortaçağ engizisyon muhakemesinde, sanık muhakemenin objesi olarak görülmekte ve cezai takibat karşısında genellikle savunmasız bırakılmaktaydı. Aydınlanma ile birlikte, ceza muhakemesinde yapılan reform hareketleri sonucunda, sanığın da her şeyden önce muhakemeye ilişkin haklarla donatılmış bir muhakeme süjesi olduğu kabul edilmiştir. Claus Roxin, Strafverfahrensrecht (C.H. Beck, München 1988) 117.

79 Foucault (n 5) 53. vd.

80 Bu konuda ayrıntılı bilgi için bkz. Füsun Sokullu Akıncı, Kriminoloji (Beta Yayınevi, İstanbul 2007$) 108$ vd.

81 Ertuğrul Uzun, 'Doğuştan Suçlular' (2003) Gün Işı̆̆ı Dergisi 19. Aydınlanma sürecinde ceza hukuku ve suç genel teorisi alanında yaşanan gelişmeler hakkında daha ayrıntılı bilgi için bkz. Rusche and Kirscheimer (n 73 ) $72 \mathrm{vd}$. 


\section{Bilimselliğin Temel Değer Haline Gelmesi ve Bilim Sayesinde Geleceğin Daha Güzel Olacağı İnancının Yaygınlaşması}

Bilim kavramı 19. yüzyılda ortaya çıkmış ve o ana kadar kullanılan “doğa felsefesi" kavramına karşılık gelmeye başlamıştır. Bilim kavramının ortaya çıkmasıyla birlikte deney ve gözlem yoluyla doğa ile ilgilenen kişilere de bilim adamı adı verilmeye başlanmıştır. ${ }^{82}$ Bununla birlikte 19 . yüzyıla gelinceye kadar, Aydınlanma döneminde, doğa felsefesi denen alanda akla dayanan rasyonalizm ile deney ve gözleme dayanan pozitivizm önem kazanmıştır.

Aydınlanma döneminde bir bilgi patlaması yaşanmıştır. Modern dönem, aydınlanma düşünürlerinin evrensel bir yasa ve evrensel bir ahlâk geliştirme çalışmaları ile şekillenmiş ${ }^{83}$ ve bunların nesnel bilim yolu ile gerçekleşeceğine inanılmıştır. Modernleşme öncesi skolastik dönem olarak adlandırılan dönemin düşünsel yapısı içinde doğru tektir ve doğruya ancak Tanrı'nın izniyle ve yine onun izin verdiği ölçüde ulaşılabilir. Modern dönem düşünce sisteminde ise doğrunun tekliği varsayımı korunmakla birlikte bu doğruya akıl ve bilim yoluyla sınırsız bir biçimde ulaşılabileceğine inanılmaya başlanmıştır. ${ }^{84}$

Modern bilim kapitalist dönüşüm ile birlikte ortaya çıkmış olup Galileo ile başladığı kabul edilmektedir. Modern bilim ilk başlarda olayların nedensellik bağından ziyade, yani neden gerçekleştiklerinden ziyade, nasıl gerçekleştiğini sorgulamıştır. "Neden?" sorusu da bilimsel yöntem için "Nasıl?" sorusu kadar elverişli olsa da nedensellik bağının sorgulanması belirli bir basamaktan sonra metafizik alana geçilmesini zorunlu kıldığından aydınlanma düşüncesinin başlarında kendisine pek yer bulamamıştır. Nitekim aydınlanma düşüncesi bilginin demistifiye edilmesi gerektiğini ve "insanın merakını bu dünyaya yönlendirmesinin en doğru şey olacağı"'n1 ${ }^{85}$ söylemektedir. Bununla birlikte ilerleyen dönemlerde modern bilim anlayışı olguları, evrende her şeyin birbiri ile ilişkili olduğu ve bu ilişkiler ağının bir makine gibi işlediği şeklinde daha nedensel bir düzlemde ele almaya başlamıştır. Bunda şüphesiz "Neden?” sorusunun bilimin dışına atılmasının oldukça zor olmasının büyük payı bulunmaktadır. $\mathrm{Bu}$ nedensellik anlayışı pozitivist bilgi anlayışının ortaya çıkmasına sebep olmuştur. Pozitivist bilgi anlayışına göre metafizik konular bilim dışına itilmelidir, böylelikle

\footnotetext{
82 Outram (n 45) 121.

83 Türkmen (n 24) 102.

84 Şaylan (n 13) 202, 203, 207.

85 Outram (n 45) 134.
} 
uzay ve zaman boyutlarının belirleyiciliği altında ölçülebilen her şey insanoğlunu evrensel olan "bilimsel bilgi"ye ulaştıracaktır. Pozitivizme göre bir önerme ya doğru ya da yanlıştır ve doğru olan "bilimsel bilgi" niteliğini kazanırken geri kalanının herhangi bir önemi yoktur. ${ }^{86}$ Esasında bilginin kaynağının yalnızca bilim olduğunu öne süren bir düşünce sistemi için "bilimsel bilgi" hatalı bir tamlama olmaktadır. Nitekim "bilimsel bilgi" kavramı başka türlü bilgilere de gönderme yapmaktadır. ${ }^{87}$ Fakat bu tamlamanın amacı birden çok bilgi türünün olabileceğini göstermekten ziyade bir iktidar kaynağı olan bilginin "bilimsel bilgi" kavramıyla daha da yüceleştirilmesi ve hatta fetişleştirilmesidir. ${ }^{88} \mathrm{Bu}$ anlamda cehaletten bilgiye geçiş süreci olarak kabul edilen aydınlanma çağının bilgiyi yaymaktan çok yasallaştırmayı ve düzenlemeyi hedeflediği görülmektedir. ${ }^{89}$ Bu yolla "bilimsel bilgi" iktidar için bir meşruiyet kaynağ 1 haline gelmekte ve "bilimsel bilgi" ışığında gerçekleştirilen bütün fiiller kendiliğinden meşru kabul edilmektedir. Tüm bu anlatılanlar sonucunda bilimsellik modern dönem için temel bir değer ve değiştirilemez bir norm haline gelmiştir.

Pozitivist bilim anlayışı bilgiyi üretenin yani bilim adamının tarafsız olacağ varsayımındadır. Tarafsız bilim adamı ise nesnel bilgiyi üretecektir. Burada bilim adamının özgün düşünceleri, değerleri, kişisel özellikleri yok sayılmaktadır. Halbuki bu özelliklerin yok sayılması mümkün değildir. Bilimsel bilgiye yüklenmiş olan bu mutlak doğru vasfi tartışmalı olduğu gerekçesi ile eleştirilmiştir. Aydınlanma sürecinde de bu tür eleştiriler zayıf da olsa kendilerine yer bulmuşlar fakat esas yankı buldukları hallerine 20. yüzyılın başlarındaki buluşlar neticesinde ulaşmışlardır. 20. yüzyıl başlarında Bohr ve Einstein gibi bilim adamlarının doğrunun zaman ve uzaydan bağımsız olarak ele alınamayacağına ilişkin çalışmaları bir yana, yalnızca bilimsel önermelerin dilsel önermeler olduğu ve dilin nesnel olamayacağı göz önüne alındığında bile bilimin nesnelliği iddiası tartı̧̧malı bir konuma düşmektedir. ${ }^{90}$ Pozitivist bilim anlayışının tarafsız bilim adamı ve nesnel bilgi varsayımı, toplum bilimleri alanında daha da ihtilaflı bir hale gelmektedir. Nitekim bilim adamı, bilgi ya da kuramını oluşturmakta olduğu toplumun aynı zamanda bir parçasıdır. Buradan hareketle neyin

86 Theodor Adorno and Max Horkheimer, Aydınlanmanın Diyalektiği (Kabalcı Yayınevi, İstanbul 2010$) 24$.

87 İnsanlar dünyayı tanımak ve anlamak için farklı bilgi türleri kullanmaktadırlar. Thomson ve Hickey tarafından yapılan bir ayrıma göre bilgi türleri deneyim, kültürel gelenek, inanç, otorite ve bilim olmak üzere beşe ayrılır. Bu sınıflandırmanın ayrıntıları ve bilgi kavramına ilişkin olarak bkz. Veysel Bozkurt, Değişen Dünyada Sosyoloji (Ekin Yayınları, Bursa 2007) 64 vd.

88 Şaylan (n 13) 198, 226.

89 Bauman (n 23) 91.

90 Şaylan (n 13) 254. 
kuram neyin ideoloji olduğunun ayrımını yapmak da kolay değildir. ${ }^{91}$

Bilimselliğin temel değer haline gelişi cezalandırma politikalarını güçlü bir biçimde etkilemiştir. ${ }^{92}$ Nedensellik kavramı, modern süreçteki bilim anlayışı neticesinde ortaya çıkmıştır. Evrenin mekanik ve nedensel algılanışı neticesinde ceza hukukunda da suçların oluşmasında, belirli hareketlerin belirli neticeleri verdiği düşünülmeye başlanmıştır. Günümüzde bile bu durumun etkileri görülmekte, yargılama aşamasında fiilin varlığının kanıtlanamadığı durumlarda suçun sabit olmadı̆̆ına kanaat getirilmektedir. Bunun yanında bilhassa pozitivist okul tarafından, bireylerin doğuştan suça eğilimli olarak dünyaya geldikleri, birtakım genetik ve yapısal özelliklerine bakılarak insanların suç işleyip işlemeyeceğinin anlaşılacağı öne sürülmüş ve bu düşünceler doğrultusunda pek çok kişi suç işlemeksizin güvenlik tedbirlerine tâbi olmuştur. Özgür irade, tehlikelilik hali, güvenlik tedbirleri gibi kavramlar bu dönemde tartışılmaya başlamış ve modern ceza hukukunun temelini oluşturmuştur. Bilhassa isnadiyet ile ilgili hususlar önem arz etmektedir. Nitekim modern öncesi dönemde suçun maddi unsuru manevi unsurdan daha önemli iken; modern dönemde, aydınlanmayla birlikte insan aklına ve irade özgürlüğüne verilen önem neticesinde, suçun manevi unsuru suçun oluşumu açısından maddi unsur ile eşdeğer kurucu nitelik kazanmıştır. ${ }^{93}$

Ayrıca belirtmek gerekir ki; modernizm yukarıda da söz edildiği gibi akıl ve bilim yoluyla doğaya egemen olunacağına ve ideal toplum düzeninin tesis edileceğine inanmaktadır. Bu inanış ilerlemeci tarih anlayışından kaynaklanmaktadır. ${ }^{94}$ İlerlenmekte olan yolun mutlu bir sonu vardır ve bir gün mutlaka bütün ihtiyaçların giderildiği, iyi, adil, çatışmadan ve tüm öngörülemezliklerden arınmış mükemmel bir topluma ulaşılacaktır. ${ }^{95}$ Mükemmel topluma ulaşma akıl ve bilim 1şı̆̆ında ortaya çıkmış kuralların uygulanması yolu ile gerçekleşecektir. Kendi aklını kullanmayan ya da bilim ile doğrudan temas etmeyen grupların ise bu kurallar doğrultusunda eğitilmesi gerektiği düşüncesi ortaya çıkmıştır. Suçlular akıl ve bilimin ilkeleri doğrultusunda 1slah edilecek ve böylelikle gelecekteki o mükemmel düzen için risk olmaktan çıkacaklar; hatta o mükemmel düzenin bir parçası haline geleceklerdir. Dolayısıyla bu bakış açısı, en

91 Şaylan (n 13) 233, 234.

92 Bu noktada Toroslu’nun aydınlanmanın ceza hukuku üzerine etkileri konusundaki şu düşüncelerini aktarmak isteriz: "Ceza hukuku bugünkü anlamıyla bilimsel niteliğe aydınlanma ile kavuşmuştur. Nitekim bu dönemde cezai kurumlara eleştirel olarak bakabilme ve tabusal bazı kurumları tartışmaya açabilme imkânı doğmuştur.” Nevzat Toroslu, 'Ceza Hukukunda Okullar', Nurullah Kunter'e Armağan (Ï̈HF Yayınları, İstanbul 1998) 367.

93 Küçüktaşdemir (n 63) 79.

94 Şaylan (n 13) 20, 74.

95 Bauman (n 23) 59. 
azından teorik olarak suçluların ıslahına imkân veren bir cezalandırma modelinin (hapishanenin) doğuşuna imkân sağlamıştır.

\section{7. "Disiplin" Kavramunın Yaygınlaşması ve "Gözetim"in Etkinliğinin Anlaşılması}

\subsection{Genel Olarak}

Hürriyeti bağlayıcı cezaların ortaya çıkışında etkili olan modern sürece ait unsurlardan bir diğeri de disiplin kavramının yaygınlaşması ve gözetimin etkinliğinin anlaşılmasıdır. Birbirinden ayrı gibi görünen bu iki husus aslında birbiriyle sıkı bir ilişki içerisindedir. Çünkü gözetim, aşağıda daha ayrıntılı açıklayacağımız üzere, etkili disipline etme yöntemlerinden biridir. Bu iki bağlantılı husustan öncelikle disiplinin yaygınlaşmasını, daha sonra ise gözetimin öneminin anlaşılmasını ayrı başlıklar altında ele almayı uygun buluyoruz.

\subsection{Disiplin Kavramının Yaygınlaşması}

Aydınlanma çağının özgürlüklerin keşfedildiği olduğu kadar disiplinlerin de keşfedildiği çağ olduğundan söz edilir. ${ }^{96}$ Aydınlanma düşüncesine göre devlet, aydınlanma düşüncesinin toplumsal pratiklerinin gerçekleşmesini sağlamakla yükümlüdür. $\mathrm{Bu}$ yükümlülük disiplin yoluyla yerine getirilmektedir. Bu bakımdan insanın özerklik aracılığıyla kendini gerçekleştireceğini söyleyen hümanist anlayışın aksine modern pratikler disiplin aracılığıyla insanı öylesine dönüştürmektedir ki benliği gerçekleştirmek imkânsız hale gelmektedir. ${ }^{97}$

Yukarıda modernizmin bir disipline etme çağı olduğuna ilişkin görüşlerden söz etmiştik. Modernleşme sürecinde Foucault'nun isimlendirmesiyle hukuksal iktidar "disiplinsel iktidar”a dönüşmeye başlar. Bu iktidar türü kendisinden öncekilerin aksine toprak ve toprağın verdiklerinden ziyade bedenler ve bedenin yaptıkları ile ilgilenir ve bedenlerden mal ve zenginlik yerine zaman ve emek elde etmeyi hedefler. Bedenlerden elde edeceği zaman ve emeği, eski yöntem olan vergi ve borç sistemleri ile değil gözetim yoluyla denetim altında tutar. ${ }^{98}$ Gerçekten disiplinci iktidar, modernleşme sürecinde, yalnızca hapishanelerde ya da yalnızca devlet iktidarı eliyle değil, toplumun tüm bölümlerinde ve kü̧̈ük iktidar şemaları aracılığıyla ortaya çıkmıştır. Eğitim alanlarından üretim

\footnotetext{
96 Foucault (n 5) 324, 336.

97 Wagner (n 55) 30, 31.

98 Veli Urhan, 'M. Foucault ve Bilgi/İktidar İlişkisinin Soykütüğü’ (2007) (9) Uludağ Üniversitesi Fen Edebiyat Fakültesi Dergisi 105.
} 
alanlarına, hastanelerden kiliselere kadar bireyler, iktidar vasitasıyla disipline edilmektedir. Sanayi toplumu basit ve rutin işleri yapan bireyler istemektedir. $\mathrm{Bu}$ durum insan yaşamının çalışmadan eğlenmeye, tüketmeden dinlenmeye tüm alanlarının kararlı bir rutin içine sokulmasını beraberinde getirmiştir ${ }^{99}$ Disiplin modern öncesi dönemden beri iktidar için önemli bir kavram olsa da modern dönemde disiplinin içeriğinde ve tekniğinde birçok değişim meydana gelmiştir. Bu bağlamda modern dönemde disiplin aracılığıyla hem bedenin gücü artmış hem de bu güç oldukça etkili bir biçimde kontrol edilerek, beden katı bir bağımlılık ilişkisi içerisine hapsedilmiştir. ${ }^{100}$

Disiplinsel iktidarın ortaya çıkışı ve toplumun tüm alanlarında yoğun bir biçimde görülmeye başlayışı modern sürecin kamusal cezalandırmayı etkileyen en önemli yönlerinden biri olmuştur. Modern dönem cezalandırma sistemlerinde mahkûm kötü huyları yok edilmesi gereken bir kişi olarak kabul edilmiş ve bu huyların yok edilmesi için bilimin gösterdiği disiplin tedbirlerinin uygulanması gerekliliği öngörülmüştür. ${ }^{101}$ Bunun için de teorik olarak suçlunun bir yere kapatılması ve burada, 1slahına yönelik disiplin yöntemlerine tâbi tutulması gereklidir. Hürriyeti bağlayıcı cezalar ise bu tür uygulamalar için biçilmiş kaftandır.

\subsection{Disipline Etme Aracı Olarak Gözetimin Öneminin Anlaşılması}

Gözetim sözcüğü ilk olarak, hakkında toplandığı bireylerin eylemlerini yönlendirmek amacıyla kullanılabilen şifrelenmiş bilgi birikimini ifade ederken; ikinci olarak, bireylerin davranışlarının, bu bireyler üzerinde otorite kuran diğer bazı bireyler tarafından doğrudan izlenmesini ifade eder. ${ }^{102} \mathrm{Bu}$ bağlamda modern cezalandırma sistemlerinin büyük anlatılarından biri, cezaların infazı sırasındaki gözetime ilişkin olarak ortaya çıkmıştır. Söz konusu anlatı "suçluların ıslahı, ancak hükümlülerin kapalı mekânlarda tutulması ve etkin şekilde gözetlenmesi halinde mümkün olabilir." şeklindedir. ${ }^{103}$

99 Şaylan (n 13) 103.

100 Foucault (n 5) 211.

101 Sulhi Dönmezer and Sahir Erman, Nazari ve Tatbiki Ceza Hukuku Genel Kısım (Cilt II) (Beta Basım Yayım, İstanbul 1994) 631.

102 Anthony Giddens, Ulus Devlet ve Şiddet (Kalkedon Yayınları, Yer Belirtilmemiş 2008) 24 vd.

103 Modern dönemde infaz kurumları dışında toplum üzerinde gerçekleştirilen gözetimin boyutlarının da arttığı görülmektedir. Bu bağlamda sosyal hayatın kurumsallaşmış bir şekilde yaygın olarak gözetimi modernizm ile birlikte ortaya çıkmıştır. Etrafta giderek artan MOBESE kameraları, PVSK m.5 kapsamında polisin hükümlü veya sanık statüsünde olmayan kimselerin dahi belirli işlemler nedeniyle parmak izlerini alma yetkisine sahip olması, önleme amaçlı iletişimin geniş çaplı dinlenmesine yönelik uygulamalar, Türkiye açısından gözetimin ne boyutlarda olduğunun en açık göstergeleridir. Modern toplumda gözetimin boyutlarını ortaya koyan ayrıntılı ve özgün bir eser için bkz. David Lyon, Elektronik Göz-Gözetim Toplumunun Yükselişi (Sarmal Yayınevi, İstanbul 1997) 42 vd. 
Bu düşüncenin oluşmasında Avrupa'da yaşanan veba salgınlarının önemli bir etkisi olmuştur. Nitekim Ortaçağ Avrupa'sında bir kentte veba salgını çıktığı zaman uygulanacak bazı kurallar oluşturulmuş, bunlara uymama da çok ağır yaptırımlara bağlanmıştı. Örneğin söz konusu kent, derhal çevrelenir ve giriş-çıkışlara kapatılır, aksine davranışlar ölümle cezalandırılırdı. Başıboş hayvanlar öldürülür; kent, her birinin başına bir denetimcinin verildiği küçük parçalara bölünürdü. Halka belirtilen günde evde kalma emri verilir, uymayanlar ölümle cezalandırılırdı. Her aile önceden erzak stoklamış olmalıydı. Sadece ekmek ve şarap için caddede ve evlerin arasında küçük tahta kanallar yapılmıştı. Bunlar mal sağlayıcılarla halk arasında, temas olmaksızın ihtiyaçların karşılamasını sağlamaktaydı. Kurallara uyulup uyulmadığı sıkı bir şekilde görevliler tarafından denetlenmekteydi. Bu sistemde teftişler sürekli, bakışlar her yerdeydi. Böylelikle vebalı kentler için getirilen bu uygulamalar sayesinde fark edildi ki, bireyleri sabit bir yere kapatmak, bütün hareketlerin denetlendiği, iktidarın hiyerarşik ve sürekli bir biçimde icra edildiği, her bireyin kapalı mekân içerisindeki hemen tüm noktalarda gözetlendiği disiplinsel bir modeli oluşturmaya imkân vermekteydi. ${ }^{104}$ Başta vebalı kentler için düşünülen bu modelin, zamanla suçluları gözaltında tutmak için de uygulanabileceği düşüncesi ortaya çıktı ve yavaş yavaş bugünkü anlamıyla hapishaneler inşa edilmeye başland.

Suçlulardan toplumu korumak ve onları terbiye etmek için, bu kimselerin kapalı mekânlarda tutulması gerektiği düşüncesinin yaygınlaşmasıyla birlikte, hapishanelerin sayısında önemli bir artış gözlenmiştir. Gelişen süreçte modern devletler, teknolojik gelişmelere paralel olarak, infaz kurumlarında bulunan hükümlüler üzerindeki gözetimin boyutlarını da arttırmışlardır. Yoğunlaşan bu gözetimin temel amacı ise hükümlüler hakkında bilgi sahibi olmak ve böylelikle onları itaate mecbur kılıp, terbiye etmektir. ${ }^{105}$

Bir nesneyi, bireyi ya da bireylerden oluşan toplumu kontrol etmek için, öncelikle onu iyi tanımak ve bilmek gerekir. Kontrol edilmek istenen nesneyi, bireyi ya da toplumu bilmek ise onu gözetlemekten geçmektedir. Modern devletin infaz kurumları da, hükümlüleri kontrol etmek için onları daha çok tanımak ve bilmek ihtiyacı içindedirler. $\mathrm{Bu}$ amaçla ellerinde olan imkânlar ölçüsünde yoğun olarak hükümlüleri gözetlerler. Bunun yanında devletin hükümlüleri gözetleme sebebi sadece bilgi edinmek değildir; aynı zamanda devlet, gözetlemek suretiyle kendi öngördüğü sınırlar dâhilinde hareket

104 Foucault (n 5) 292.

105 "İktidar bilgiye gereksinim duyar; bilgi iktidara meşruluk ve etkililik kazandırır (bunların birbiriyle bağlantısız olması gerekmez.) Bilgiye sahip olmak iktidardır" Bauman (n 23) 62. 
eden ve koyduğu kurallara uyan bireyler oluşturmak için gözetlemeyi bir terbiye aracı olarak da kullanır. Bu bağlamda, devletin hükümlü hakkında gözetimle bilgi edinmesi, çoğu kez gözetlenenin (hükümlünün) terbiye edilmesi ile eş zamanlı olarak gerçekleşir. ${ }^{106}$

Modern dönemde cezalandırmanın belirli bir kapalı mekânda gerçekleştirilmesi ve böylelikle gözetimin etkinleştirilmesi konusunda, Bentham’ın ortaya koyduğu "Panopticon" isimli hapishane projesi, çok önemli ipuçları vermektedir. Görülmeden gözetlemeye olanak veren bu hapishane, sürekli görmeye ve hemen tanımaya olanak veren mekânsal birimler oluşturmaktadır. ${ }^{107} \mathrm{Bu}$ itibarla panopticon sadece bir hapishane değil, bir iktidar teknolojisi, bir gözetim projesidir. ${ }^{108}$ Nitekim Bentham bu projede, hem mahkûmları gözetleyerek bilgilenmeyi hem de onları ıslah etmeyi amaçlamıştır. Bentham Faydacı Hukuk Okulu'nun kurucusu olarak kabul edilir. Faydacı Hukuk Okulu kökenini hedonizmden alır ve fayda ilkesi bu okulun temel ilkesidir. Faydacı Hukuk Okulu'na göre “doğal hak” diye bir kavram söz konusu değildir ve haklar birbirine tercih edilebilir. Bu durum hukukun ekonomik analizini mümkün kılmakta ve panoptikon hukukun ekonomik analizi neticesinde tasarlanan bir hapishane olarak karşımıza çıkmaktadır. ${ }^{109}$ Bentham'dan sonra özellikle 19. yüzyılın ilk yarısında inşa edilen hemen tüm hapishaneler bir şekilde Bentham'ın projesine atfen, onun bazı uygulamalarını örnek almak suretiyle yapılmışlardır. ${ }^{110} \mathrm{Bu}$ bağlamda gözetiminin öneminin batı dünyasınca keşfi de hapishanelerin ortaya çıkışını tetiklemiştir.

106 Hakan Karakehya and Asena Kamer Usluadam, 'Neden Gözetl(en)iyoruz?' (2016) 2 (3- Akar Öcal'a Armağan) Anadolu Üniversitesi Hukuk Fakültesi Dergisi 190 vd.

107 Ana hatlarıyla Panopticon'da, halka halinde bir bina, bu halkanın ortasında yani merkezde ise bir kule vardır. Ortadaki bu gözetleme kulesinin, onun etrafını saran halka şeklindeki binanın iç cephesine bakan geniş pencereleri bulunmaktadır. Halka şeklindeki bina hücrelere bölünmüştür. Hücrelerin de biri içeri diğeri dışarı bakan iki büyük penceresi vardır. İçeri bakan pencere tam kuleninkilerin karşısına denk gelmektedir. Dışarıya bakan pencereden gelen ışı sayesinde, halka şeklindeki binanın içinde yer alan hücrelerdeki mahkûmların siluetlerini, kuleden rahatlıkla takip etmek mümkündür. Kulenin içerisi dıșarı yansımadığı için de, kulede kaç kişinin olduğunu bilmek hücredekiler bakımından mümkün değildir. Jeremy Bentham, Panoptikon: Gözün Iktidarı (Su Yayınları, İstanbul 2008) 14-16.

108 Michel Foucault, İktidarın Gözü (Ayrıntı Yayınevi, İstanbul 2003) 87. İzlenip izlenmediğini, kulenin içerisini göremediği için bilemeyen ama orada izlemek için birilerinin var bulunduğunu varsaymak durumunda olan mahkûm açısından tek makul seçenek itaattir. Bu nedenle Bentham, hapishanesi için Yunancaya dayanan "göz önündeki yer" anlamında bir kelime türetmiştir: "Panopticon". Hem kolay gözetleme olanağı hem de mahkûm üzerinde oluşturduğu "sürekli gözetleniyorum" hissi nedeniyle, bu hapishanenin çok sayıda gardiyana ihtiyac1 yoktur. Lyon (n 103) 93.

109 Küçüktaşdemir (n 63) 66.

110 Foucault (n 108) 86. 


\section{Sonuç}

Hapishane modern bir icattır. Her ne kadar modern öncesi dönemde hapishaneyi andıran (zindan vb.) uygulamalar olsa da örgütlü olarak yapılandırılmış ve yaygın şekilde hapishanenin ortaya çıkışı, modern dönemin başlangıcına tekabül etmektedir. Bu bağlamda insanlığın modern sürece geçişinin koşulları, aynı zamanda hapishanenin ortaya çıkmasının da koşullarını oluşturur.

Modern süreç, özellikle 17. yüzyılın ikinci yarısından itibaren Avrupa'da başlayan ve sonrasında tüm dünyayı etkisi altına alan, sosyal, ekonomik ve kültürel değişim sürecini ifade eder. Modern sürecin ya da daha yaygın kullanımı ile modernizmin üç temel sacayağı vardır. Bunlar; sanayileşme, sanatsal-kültürel değişim ve aydınlanmadır. Modern sürecin başkaca unsurları da olmakla birlikte, bu üç unsur modernizmin üzerine inşa edildiği unsurlar olmaları dolayısıyla daha fazla önem arz eder. Demokratikleşme, evrenselleşme, özgürleşme, ulus devlet gibi başkaca unsurlar ise bu üç temel unsur sayesinde var olmuş veya bu üç unsurdan birisinin toplumsal yansıması olarak ortaya çıkmıştır.

Modern sürecin kamusal cezalandırmanın değişimine ve dolayısıyla hapishanenin doğuşuna zemin hazırlayan alt unsurları ise; 1) İnsanın öneminin artması, 2) Bilimselliğin temel değer haline gelerek, yarının daha güzel olacağı inancının yaygınlaşması, 3) Disiplin kavramının yaygınlaşması ve gözetimin öneminin farkına varılması şeklinde siralandırılabilir.

Gerek insan bedeninin öneminin artması gerekse de insanın kendi yaşam yolunu özgür iradesiyle ve aklıyla belirleyebilen bir birey olarak görülmeye başlanması, ona karşı insan onuruyla bağdaşmayan ve doğrudan fiziksel şiddet içeren cezaların uygulanamayacağı düşüncesini ortaya çıkarmıştır. Böylelikle fiziksel şiddet içeren cezalar oldukça hızlı biçimde terk edilmiş ve suçlunun eğitilerek toplumla uyumlu bir birey haline getirilmesine olanak sağladığı düşünülen, hürriyeti bağlayıcı cezaların ortaya çıkışının önünü açmıştır.

Bilimselliğin temel değer haline gelmesi ve bilim sayesinde yarınların insanlık için daha güzel olacağı düşüncesinin yaygınlaşması ise suçluların da bilim yoluyla sslah edilebileceği ve topluma kazandırılarak düzen ve refah içinde bir toplum oluşturulacağ 1 düşüncesini ortaya çıkarmıştır. Bu düşünceye göre; "insan aklının ve onun aracıllığıyla ortaya konulan bilimsel bilginin yapabileceklerinin sınırı bilinemeyecek kadar geniştir. Dolayısıyla suçlu insanın 1slahı, bilimsel bilginin rahatlıkla aşabileceği bir sorundur. Suç işleme oranlarının neredeyse sıfırlandı̆̆ bir refah toplumu inşa edilmesi çok da 
uzak değildir. Yarın bugünden daha güzel olacaktır.” Bu şekilde suçluların bilimsel yöntemlerle 1slah edilmesi ise onların bir yerde kapalı tutulmasını ve 1slah sürecinden geçirilmesini gerekli kılmaktadır. O günkü koşullarda buna imkân verecek yegane cezalandırma sistemi olarak da hürriyeti bağlayıcı cezalar ortaya çıkmıştır.

Son olarak disiplin kavramı da modern süreçte yaygınlaşmış ve toplum içinde disiplini sağlamanın en etkili aracının gözetim olduğu görülmüştür. Buna göre, bir kimseyi, bir insan grubunu ya da makro ölçekte bir toplumu kontrol etmek ya da yönlendirmek için onu iyi bilmek, iyi bilmek için de gözetlemek gereklidir. Bu bağlamda "bir kişi ya da şeyi iyi gözetleyen, iyi bilir; iyi bilen de onu kontrol eder.” düşüncesi yaygınlaşmıştır. Ayrıca bir otorite ilişkisi içerisinde gözetlenen kimsenin disipline edildiği ve kurallara uygun davranmasının sağlandığı da keşfedilmiştir. Bu keşfin yapılmasında orta çağ Avrupa'sında ortaya çıkan veba salgınının önemli etkisi olmuştur. Nitekim salgın tehlikesiyle karantina altına alınan bölgelere salgınla mücadele için yoğun bir gözetim uygulanmış, böylelikle karantina bölgesindeki insanların disipline edildiği ve kurallara uymasının etkin şekilde sağlandığı gözlenmiştir. Hükümlülerin bir yere kapatılarak gözetlenmesi hem onlar hakkında daha iyi bilgi edinilmesini sağlamak hem de onları disipline etmek bakımından çok etkili bir yoldu. Bu tespit de hapishane fikrinin Avrupa'da hızla yaygınlaşmasını sağlamış ve akabinde hürriyeti bağlayıcı ceza uygulamaları Avrupa'dan neredeyse tüm dünyaya yayılmıştır.

Hakem Değerlendirmesi: Dış bağımsız.

Çıkar Çatışması: Yazarlar çıkar çatışması bildirmemiştir.

Finansal Destek: Yazarlar bu çalışma için finansal destek almadığını beyan etmiştir.

Peer-review: Externally peer-reviewed.

Conflict of Interest: The authors have no conflict of interest to declare.

Grant Support: The authors declared that this study has received no financial support.

\section{Kaynakça/References}

Adorno, T. / Horkheimer, M. Aydınlanmanın Diyalektiği (Kabalcı Yayınevi, İstanbul 2010).

Akbulut, B., Ceza Hukuku Genel Hükümler (Adalet Yayınevi, Ankara 2019).

Artuk, M.E. / Gökcen, A. /Yenidünya, A.C., Ceza Hukuku Genel Hükümler (Adalet Yayınevi, Ankara 2012).

Bahar, H.İ., 'Hapishaneler, Sorunlar ve Çözüm Arayışları', Hapishane Kitabı (Kitabevi Yayınları, İstanbul 2005).

Bauman, Z., Akışkan Modernite (Can Sanat Yayınları, İstanbul 2017).

Bauman, Z., Yasa Koyucular ile Yorumcular (Metis Yayınları, İstanbul 2017).

Beccaria, C., Suçlar ve Cezalar Hakkında (İmge Kitabevi, Ankara 2016).

Bentham, J., Panoptikon: Gözün İktidarl (Su Yayınları, İstanbul 2008).

Bıçak, V., Suç Muhakemesi Hukuku (Seçkin Yayıncılık, Ankara 2011). 
Bozkurt, V., Değişen Dünyada Sosyoloji (Ekin Yayınları, Bursa 2007).

Daştan, N., 'Cennetten Kovulma Motifinin Semavi Dinler ile Bazı Mitolojilerdeki (Sümer, Türk ve Yunan) Görünümü’ (2014) (36) Türklük Bilimi Araştırmaları Dergisi 61-81.

Day, F.D., 'Ceza Hukukunun Kökeni ve Doğası' (2011) 6 (16) Ceza Hukuku Dergisi 240-247.

Demirbaş, T., 'Hürriyeti Bağlayıcı Cezaların ve Cezaevlerinin Evrimi', Hapishane Kitabı (Kitabevi Yayınları, İstanbul 2005).

Demirbaş, T., Ceza Hukuku Genel Hükümler (Seçkin Yayıncılık, Ankara 2016).

Dönmezer, S. / Erman, S., Nazari ve Tatbiki Ceza Hukuku Genel Klsım (Cilt II) (Beta Basım Yayım, İstanbul 1994).

Farthing, S., Sanatın Tüm Öyküsü (Hayalperest Yayınevi, İstanbul 2012).

Foucault, M., İktidarın Gözü (Ayrıntı Yayınevi, İstanbul 2003).

Foucault, M., 'Aydınlanma Nedir?' (2005) 10 (38-39) Liberal Düşünce 231-235.

Foucault, M., Hapishanenin Doğuşu (İmge Kitabevi, Ankara 2017).

Fulberth, G., Kapitalizmin Klsa Tarihi (Yordam Kitap, İstanbul 2011).

Gençoğlu, A.Y., ‘Ticari Kapitalizmden Sanayi Kapitalizmine: Merkantalizm, Liberalizm ve Marksizm' (2013) 7 (14) Toplum Bilimleri Dergisi 79-94.

Giddens, A., Ulus Devlet ve Şiddet (Kalkedon Yayınları, Yer Belirtilmemiş 2008).

Giddens, A., Modernliğin Sonuçları (Ayrıntı Yayınları, İstanbul 2018).

Gökberk, M., Felsefe Tarihi (Remzi Kitabevi, İstanbul 2008).

Günay, D., 'Sanayi ve Sanayi Tarihi’ (2002) (31) Mimar ve Mühendis Dergisi 8-14.

Hobsbawm, E., Devrim Çă̆ı (Dost Kitabevi, Ankara 2013).

Horkheimer, M., Akıl Tutulması (Metis Yayınları, İstanbul 2005).

Kaboğlu, İ.Ö., Dayanışma Hakları (TODAİE Yayınları, Ankara 1996).

Kant, I., Aydınlanma Nedir? < https://www.istabip.org.tr/site_icerik/2017/haberler/kasim/aydinlanma_nedir_kant. pdf>

Karakehya, H., 'Modern Cezalandırma Sistemlerinin Büyük Anlatıları’ (2008) 66 (1) İstanbul Üniversitesi Hukuk Fakültesi Mecmuası 87-108.

Karakehya, H., 'Tanzimat Sonrası Osmanlı Devletinin Kamusal Cezalandırma Sisteminde Yaşanan Değişim', Prof. Dr. Nevzat Toroslu’ya Armağan (Ankara Üniversitesi Yayınları, Ankara 2015).

Karakehya, H, 'Hürriyeti Bağlayıcı Cezaların İnfazıyla Hükümlünün Islahının Sağlanması Mümkün Müdür?', Dr. Dr. h.c. Silvia Tellenbach’a Armağan (Seçkin Yayıncılık, Ankara 2018).

Karakehya, H. / Usluadam, A.K., 'Neden Gözetl(en)iyoruz?' (2016) 2 (3- Akar Öcal'a Armağan) Anadolu Üniversitesi Hukuk Fakültesi Dergisi 187-200.

Kazgan, G., İktisadi Düşünce veya Politik İktisadın Evrimi (Remzi Kitabevi, İstanbul 2000).

Keleş, R., Kentleşme Politikası (İmge Kitabevi, Ankara 2016).

Koca M. / Üzülmez İ., Türk Ceza Hukuku Genel Hükümler (Seçkin Yayınevi, Ankara 2019).

Küçüktaşdemir, Ö., ‘Aydınlanma ve Ceza Hukuku’ (2014) (113) Türkiye Barolar Birliği Dergisi 57-98.

Le Guin, U.K., Mülksüzler (Metis Yayınları, İstanbul 2019).

Locke, John Yönetim Üzerine İkinci İnceleme (Ebabil Yayınları, Ankara 2012)

Lyon, D., Elektronik Göz-Gözetim Toplumunun Yükselişi (Sarmal Yayınevi, İstanbul 1997).

Lyotard, J.F., Postmodern Durum (Vadi Yayınları, Ankara 2000).

Marshall, G., 'Evolutionism', Oxford Dictionary of Sociology (Oxford University Press, New York 1998).

Outram, D., Aydinlanma (Dost Kitabevi, Ankara 2007). 
Özcan, M.T., Modern Toplum ve Hukuk Devleti (XII Levha Yayınları, İstanbul 2008).

Özgenç, İ., Türk Ceza Hukuku Genel Hükümler (Seçkin Yayıncılık, Ankara 2019).

Rousseau, Jean Jacques Toplum Sözleşmesi, (Türkiye İş Bankası Kültür Yayınları, İstanbul, 2006)

Roxin, C., Strafverfahrensrecht (C.H. Beck, München 1988).

Rusche, G. /Kirscheimer, O., Punishment and Soical Structrue (Transaction Publishers, New Brunswick and London 2003).

Sokullu Akınc1, F., Kriminoloji (Beta Yayınevi, İstanbul 2007).

Şaylan, G., Postmodernizm (İmge Kitabevi, Ankara 2016).

Toroslu, N., ‘Ceza Hukukunda Okullar', Nurullah Kunter’e Armağan (IÜHF Yayınları, İstanbul 1998).

Turani, A., Dünya Sanat Tarihi (Remzi Kitabevi, İstanbul 2013).

Türkmen, M., Modernleşme ve Hukuk Türkiye'de Ceza Adalet Sistemi ve Denetimli Serbestlik (Doğu Kitabevi, İstanbul 2018).

Urhan, V., 'M. Foucault ve Bilgi/İktidar İlişkisinin Soykütüğü'(2007) (9) Uludağ Üniversitesi Fen Edebiyat Fakültesi Dergisi 99-118.

Uzun, E., 'Doğuştan Suçlular' (2003) Gün Işı̆̆ı Dergisi 19-21.

Wagner, P., Moderniğin Sosyolojisi (Ayrıntı Yayınları, İstanbul 2005).

Weber, M., Protestan Ahlakı ve Kapitalizmin Ruhu (Ayraç Yayınevi, Ankara 1999).

Zafer, H., Ceza Hukuku Genel Hükümler (Beta Yayınevi, İstanbul 2019).

Zekiyan, B., Hümanizm (İnsancılık) Düşünsel İçlem ve Tarihsel Kökenler (İnkılap Kitabevi, İstanbul 2005).

$<$ https://www.kitabimukaddes.com/kutsal-kitap-hakkinda-bilgilendirme-ve-tam-metni/eski-antlasma/yaratilis> $<$ https://kuran.diyanet.gov.tr/mushaf/kuran-meal-2/bakara-suresi-2/ayet-36/diyanet-isleri-baskanligi-meali-1> $<$ https://kuran.diyanet.gov.tr/mushaf/kuran-meal-2/araf-suresi-7/ayet-24/diyanet-isleri-baskanligi-meali-1> 
